\title{
$\mathrm{C}|\mathrm{E}| \mathrm{D}|\mathrm{L}| \mathrm{A} \mid \mathrm{S}$
}

Centro de Estudios

Distributivos, Laborales y Sociales

Maestría en Economía

Facultad de Ciencias Económicas

Universidad Nacional de la Plata

\section{Is the Glass Half Empty or Half Full? Enrollment, Graduation, and Dropout Rates in Latin America}

Marina Bassi, Matias Busso y Juan Sebastián Muñoz

Documento de Trabajo Nro. 170

Octubre, 2014

ISSN 1853-0168 


\title{
Is the Glass Half Empty or Half Full? Enrollment, Graduation, and Dropout
}

\author{
Rates in Latin America ${ }^{1}$
}

\author{
Marina Bassi \\ Education Division \\ Inter-American \\ Development Bank
}

\author{
Matias Busso \\ Research Department \\ Inter-American \\ Development Bank
}

\author{
Juan Sebastián Muñoz \\ Department of Economics \\ University of Illinois at \\ Urbana-Champaign
}

September, 2014

\begin{abstract}
We use 292 household surveys from 18 Latin American countries to document patterns in secondary school graduation rates over the period 1990-2010. We find that enrollment and graduation rates increased during that period while dropout rates decreased. We provide two types of explanations for these patterns. Countries implemented changes on the supply side to increase access, by increasing the resources allocated to education and designing policies to help students staying in school. Despite this progress, graduation rates are still generally low, there still persist remarkable gaps in educational outcomes in terms of gender, income quintiles, and regions within countries, and the quality of education is generally low.
\end{abstract}

JEL: I21, I24, O54.

Keywords: Secondary school, graduation, enrollment, dropout, Latin America.

\footnotetext{
${ }^{1}$ Corresponding authors: Marina Bassi (marinab@iadb.org) and Matias Busso (mbusso@iadb.org). We thank Richard Murnane, Juliana Chen Peraza, Hugo Ñopo, two anonymous referees, and seminar participants at various institutions for helpful comments. We also thank Daniel Alonso for his assistance with the database of policy variables. Dario Romero Fonseca provided excellent research assistance during the revision of the paper. Errors are our own. The views expressed herein are those of the authors and should not be attributed to the Inter-American Development Bank.
} 


\section{Introduction}

The average years of education of the population across the world have increased dramatically in the last sixty years and Latin America was no exception. ${ }^{2}$ A larger fraction of Latin American children and youth are now able to attend secondary school -especially among vulnerable families that were otherwise excluded from the education system. This large expansion brought with it a greater student heterogeneity, which increased the challenges of retaining children in school until graduation as well as providing a good quality of education for all students. Despite the magnitude of these changes, few attempts have been made to document and explain the patterns and trends of enrollment, graduation and dropout rates in Latin America over the last two decades. This is what we do in this paper.

High school graduation has been a major concern in developed countries such as the United States (US). After showing an extraordinary growth from 6 percent in the beginning of the $20^{\text {th }}$ century to around 80 percent in the early 1970s, high school graduation rate stagnated or even slightly declined over the following three decades (Heckman and Lafontaine, 2010; Murnane, 2013). This stagnation led many to refer to the problem as the dropout crisis or epidemic. Concerns with completion of secondary education in the US. generated a great deal of attention from researchers and government institutions, which led to an intense debate and a large literature on the measurement and definition of graduation and dropout rates. This literature presents a very wide range of estimates. As stated in Heckman and Lafontaine (2010, pp. 244) "Depending on the data sources, definitions, and methods used, the US graduation rate is claimed to be anywhere from 66 percent to 88 percent in recent years - a wide range for such a basic educational statistic".

Following Heckman and Lafontaine (2010) and Murnane (2013), this paper examines patterns and trends of educational outcomes (in terms of graduation, dropout, enrollment, and overage rates) over the period 1990 to 2010 in 18 Latin American countries for which comparable data from household surveys are available. In view of the significant changes in the education systems, it is relevant for educational policies to have a clearer picture about these empirical

\footnotetext{
${ }^{2}$ These drastic gains were part of a trend that similarly affected most regions of the world. In advanced economies the ratio of secondary school graduates to population aged 15 or more increased from 12.7 percent in 1950 to 37.7 percent in 2010, while in East Asia it improved from 4.2 percent to 38.1 percent in the same period (Barro and Lee, 2013).
} 
regularities, its plausible explanations, and the potential challenges that educational policy makers might have in the near future.

We pay special attention to build statistics that are comparable over time and across countries. Even though we document levels and trends for several educational outcomes by country, we try not to emphasize individual countries' dynamics. The ultimate goal is to find common trends. The paper focuses mainly on secondary education, although it also analyzes educational outcomes in primary education as a precondition to be able to enroll in secondary education. We also explore heterogeneity in terms of countries, gender, income, and region, and we analyze outcomes for different birth cohorts.

We show that graduation rates in Latin America have improved remarkably since the early 1990s. The percentage of students graduating from primary and secondary school on time increased in the majority of countries included in our sample. Countries that showed lower graduation rates in the early 1990s have experienced larger improvements in graduation rates (especially in primary), converging towards countries that started with higher graduation rates in the beginning of the period analyzed. In addition, on average in the region every birth cohort since the early twentieth century shows a higher graduation rate in primary and secondary education than previous generations. The moment of the highest probability school dropout in the education cycle shifted from primary and the transition to secondary, to later in secondary schooling, implying that students stay longer in the education system.

Our results suggest that the increase in secondary school graduation can be associated with three factors: an increase in enrollment and graduation of primary schools and in the efficacy of secondary schools to capture and retain those graduates; an increase in expected returns to education which provided economic incentives to stay in secondary school; and several education policies implemented in the region. The improvement in the secondary school graduation rates shows a glass half full.

Big challenges remain, however, in terms of secondary school performance: graduation rates in the region are low relative to developed countries; a large fraction of young students drops out from school before completing secondary school; there are still important differences in achievement levels among students in urban and rural areas, among families with high and low 
levels of income, and among countries; and, finally, education quality is well below other countries with similar GDP. These challenges show a glass half empty.

This paper is organized as follows. Section 2 describes the data. Section 3 discusses the way in which we measure educational outcomes. Section 4 presents patterns on Latin America's secondary school indicators. Section 5 shows the main explanations for the increase in secondary education graduation rate. Section 6 discusses the region's education challenges. Section 7 concludes.

\section{Data}

Our analysis is based on 292 household surveys carried out in 18 Latin American countries and in the US during the period 1990-2010. ${ }^{3}$ In the online appendix we provide further details about surveys including their regional and time coverage. ${ }^{4}$ Household surveys in Latin America are one of the few available data sources to analyze schooling decisions for different cohorts and for different time periods. They also allow us to build measures with common definitions that are comparable across countries and time. They cover people of all ages, have information both on schooling achievement and labor market outcomes, and have annual frequency which is useful to study trends and breaks in the time series. ${ }^{5}$

The main limitation of household surveys in Latin America is that questionnaires and sampling definitions vary somewhat across countries and, in some cases, have changed during the period of analysis for the same country. ${ }^{6}$ In order to lessen this limitation we made country samples

\footnotetext{
${ }^{3}$ The surveys include individual level data from Argentina, Bolivia, Brazil, Chile, Colombia, Costa Rica, Dominican Republic, Ecuador, Guatemala, Honduras, Mexico, Nicaragua, Panama, Paraguay, Peru, El Salvador, Uruguay, Venezuela, and US. In the cases of Guatemala we had no information for the period 1990-1995.

${ }^{4}$ The online appendix can be found in www.matiasbusso.org/papers jointly with a dataset of all the statistics described in this paper. The online appendix contains also supplemental statistics.

${ }^{5}$ Estimates of graduation and dropout rates are affected by the source of information analyzed. Heckman and LaFontaine (2010) estimate high school graduation rates in the US applying a unified methodology to different sources of data. They argue that in the US household surveys can result in an overestimation of graduation rates (because they do not include military or incarcerated populations) while administrative data can lead to an underestimation of the graduation rates.

${ }^{6}$ For example, Argentina changed from the Encuesta Permanente de Hogares to the Encuesta Permanente de Hogares Continua in 2003, or Colombia moved from the Encuesta Continua de Hogares to the Gran Encuesta Integrada de Hogares in 2006.
} 
comparable by keeping constant geographical areas and unifying the legal starting/finishing age in each school cycle. Most surveys have national coverage except in the cases of Argentina, Bolivia, Ecuador, and Uruguay that only cover urban areas. Therefore, statistics for these countries are less comparable with those of other countries.

We also use several auxiliary sources of information. First, we compile a set of measures of schooling indicators from UNESCO, including number of teachers, expansion of mandatory education, enrollment in private schools, and others. Second, we complement this dataset with a group of policy variables that capture the implementation of conditional cash transfers programs, education decentralization laws, the introduction of flexible modalities of secondary schooling, changes in mandatory starting school age, and changes in the legal duration of schooling cycle. We construct these policy variables based on information published in the literature and in websites of the Ministries of Education. ${ }^{7}$ Finally, we use data from the Program for International Student Assessment (PISA) to measure school quality and relate it to the observed trends in enrollment and graduation.

\section{Measurement and Definitions}

The computation of school enrollment, graduation, and dropout rates would ideally use longitudinal data of a representative sample of a country's population, which allows the researcher to follow the same individuals over time and observe their transition from one state (e.g. being in school) to another state (e.g. graduate or dropout). Although in Latin America some household surveys include panel data sets, they track individuals for relatively short periods of time (up to two years) and suffer substantial attrition. Thus, the estimates in this paper are calculated using multiple cross sections.

We start with some definitions. For schooling level $k \in\{p=$ primary, $s=$ secondary $\}$ let: $\mathrm{E}_{\mathrm{k}}$ denote the event of being enrolled in schooling level $k, \mathrm{D}_{\mathrm{k}}$ the event of not being enrolled in schooling level $k ; \mathrm{G}_{\mathrm{k}}$ denote the event of having graduated from that schooling level; $\mathrm{L}_{\mathrm{k}}$ the

\footnotetext{
${ }^{7}$ Stampini and Tornarolli (2012) present a review of all CCTs programs in Latin America, which is the main source of information for the construction of the CCT policy variable used in this paper. We complemented this information with OVE (2013). For the decentralization policy variable, the main source is Navarro, J.C. (2007).
} 
event of lagging behind more than one year in that schooling level (according to the individuals age relative to the legal starting/finishing age); $A_{k}$ the event of being in the legal age group corresponding to schooling level $k$; and $F_{k}$ the event of having an age which is equal to the legal finishing age from schooling level $k$ plus one.

The function $N(X \mid Y)$ provides the number of people for whom the event $X$ holds conditional on the occurrence of the event $Y$. We can estimate different probabilities of events $\left\{E_{k}, G_{k}, D_{k}, L_{k}\right\}$ using their sample analogues. We call unconditional probabilities those that provide information about an individual in a certain age group regardless of his past schooling achievement. Conditional probabilities, on the other hand, capture the probability of an event for particular subgroups within an age group (e.g. the percentage of individuals of secondary school age that graduated from the primary school level).

Table 1: Enrollment, Graduation, Dropout and Overage Measures

\begin{tabular}{lcc}
\hline & Unconditional & Conditional \\
\hline $\begin{array}{l}\text { Enrollment rate } \\
\text { in school level } k\end{array}$ & $\hat{P}\left(E_{k}\right)=\frac{N\left(E_{k} \mid A_{k}\right)}{N\left(A_{k}\right)}$ & $\hat{P}\left(E_{k} \mid G_{k-1}\right)=\frac{N\left(E_{k} \mid A_{k}, G_{k-1}\right)}{N\left(A_{k}, G_{k-1}\right)}$ \\
\hline $\begin{array}{l}\text { Graduation rate from } \\
\text { school level } k\end{array}$ & $\hat{P}\left(G_{k}\right)=\frac{N\left(G_{k} \mid F_{k}\right)}{N\left(F_{k}\right)}$ & $\hat{P}\left(G_{k} \mid E_{k}\right)=\frac{N\left(G_{k} \mid F_{k}, E_{k}\right)}{N\left(F_{k}, E_{k}\right)}$ \\
\hline $\begin{array}{l}\text { Dropout rate } \\
\text { from school level } k\end{array}$ & $\hat{P}\left(D_{k}\right)=\frac{N\left(\neg E_{k} \mid A_{k}\right)}{N\left(A_{k}\right)}$ & $\hat{P}\left(D_{k} \mid G_{k-1}\right)=\frac{N\left(\neg E_{k} \mid A_{k}, G_{k-1}\right)}{N\left(A_{k}, G_{k-1}\right)}$ \\
\hline $\begin{array}{l}\text { Overage rate } \\
\text { in school level } k\end{array}$ & $\hat{P}\left(O_{k}\right)=$ & $\hat{P}\left(O_{k} \mid G_{k-1}\right)=$ \\
\end{tabular}

Latin American educational systems vary in their definitions of mandatory school age. Thus, to estimate these probabilities we use information on starting primary school age and duration of primary and secondary school in order to build three country-specific age intervals: primary, secondary, and post-secondary schooling age. The exact date in which mandatory school begins for any given individual is typically determined by her date of birth. Since this information is usually not observed we construct the primary school interval by considering only children that are at least one year older than the primary school starting age and have less than the secondary school starting age. Similarly, the secondary school interval age group includes persons that are 
of secondary starting age to secondary finishing age. ${ }^{8}$ Table 1 provides the formal definitions of conditional and unconditional rates measured in this paper.

For example, the secondary school unconditional enrollment rate $\hat{P}\left(E_{s}\right)$ is defined as the number of secondary school age individuals that are enrolled in secondary school, $N\left(E_{s} \mid A_{s}, G_{p}\right)$, divided by the population with secondary school age, $N\left(A_{s}\right) .^{9}$ The secondary school conditional enrollment rate, $\hat{P}\left(E_{s} \mid G_{p}\right)$ only takes into account people that are eligible to be in secondary school and therefore divides by the population with secondary school age that have completed primary school, $N\left(A_{s}, G_{p}\right)$.

Similarly, the secondary school unconditional graduation rate $\hat{P}\left(G_{s}\right)$, is calculated as the population who -being one year older that the legal finishing age for secondary school- has graduated from secondary school, $N\left(G_{S} \mid F_{S}\right)$, divided by the population of individuals that are one year older than the legal graduation age at the secondary school level, $N\left(F_{s}\right)$. This ratio is a relevant indicator of the efficiency of the education system as a whole. However, it does not capture the graduation rate among those that were eligible to enroll in secondary school. The reason is that some of the individuals in this age range did not complete primary school and, consequently, could not start secondary school. To account for this, the conditional graduation rate uses as the denominator the population that is one year or older than the secondary school legal finishing age that have completed primary school and enrolled in secondary school, $N\left(F_{S}, E_{s}\right)$. This indicator is a better proxy of the efficiency of education systems at the secondary school level. Note that the conditional secondary school graduation rate could improve at the same time that the unconditional rate worsens. This would happen if larger school abandonment happens before students graduate from primary school and, at the same time, a larger proportion among those that do enroll in secondary school graduates.

The unconditional dropout rate at the secondary school level is calculated as the population with secondary school age who are not enrolled in secondary school divided by the population with

\footnotetext{
${ }^{8}$ The online appendix also presents results for the post-secondary school population which refers to people over secondary finishing age, but younger than 26 years old.

${ }^{9}$ Age ranges are defined according to the legal starting and finishing age in each country, as explained above.
} 
secondary school age, $N\left(\neg E_{S} \mid A_{s}\right) / N\left(A_{S}\right) .{ }^{10}$ The conditional dropout rate in secondary school conditions on having finished primary school, $G_{p}$. That is, it uses as denominator the population with secondary school age who has completed primary education. Once again, the unconditional rate captures the overall dropout rate among the secondary age range youths, while the conditional rate measures abandonment among those that have ever been enrolled in secondary school.

The secondary school overage rate is the proportion of people that are still enrolled in secondary school but lag behind schedule in terms of completed education years. Using the same criteria as above, unconditional overage rates compute the proportion based on individuals in the secondary school age and conditional overage rate takes the subgroup that has graduated from primary school. ${ }^{11}$

We compute all probabilities for all countries, years and groups using country-year specific weights in order to obtain national (or urban) representative values. Since we do not have continuous series we interpolate the missing values.

\section{Patterns and Trends: A Glass Half Full}

In order to provide a comprehensive overview of the education systems in the 18 Latin American countries (LAC), Table 2 presents the unconditional probabilities of enrollment, graduation, dropout, and overage in the early 1990s and late 2000s. ${ }^{12}$ To avoid small sample sizes and to reduce the effect of aggregate temporary shocks, we include more than one cross-section/year in each of the sub-periods whenever possible. As a reference we also provide statistics for the US and for the Latino population born in the US. In addition we compute a simple average and a population-weighted for LAC.

\footnotetext{
${ }^{10}$ Note that, by construction, the unconditional dropout rate is the complement of the unconditional enrollment rate.

${ }^{11}$ Analogous criteria were applied to enrollment, graduation and dropout rates at the primary school level. However, in this case conditional and unconditional rates are the same, since in general, in the years and countries included in this study, there were no pre-requisites in terms of schooling to enroll in primary school. This changed in some countries after reforms in the mandatory years of education. However, in some instances the reforms were relatively recent and might not have affected the cohorts analyzed in this paper.

${ }^{12}$ The early 1990s refer to years circa 1990-1995 while the late 2000s refer to years circa 2006-2010. See Appendix Table 1 for further details. All the appendix tables can be found online in www.matiasbusso.org or obtained from the authors upon request.
} 


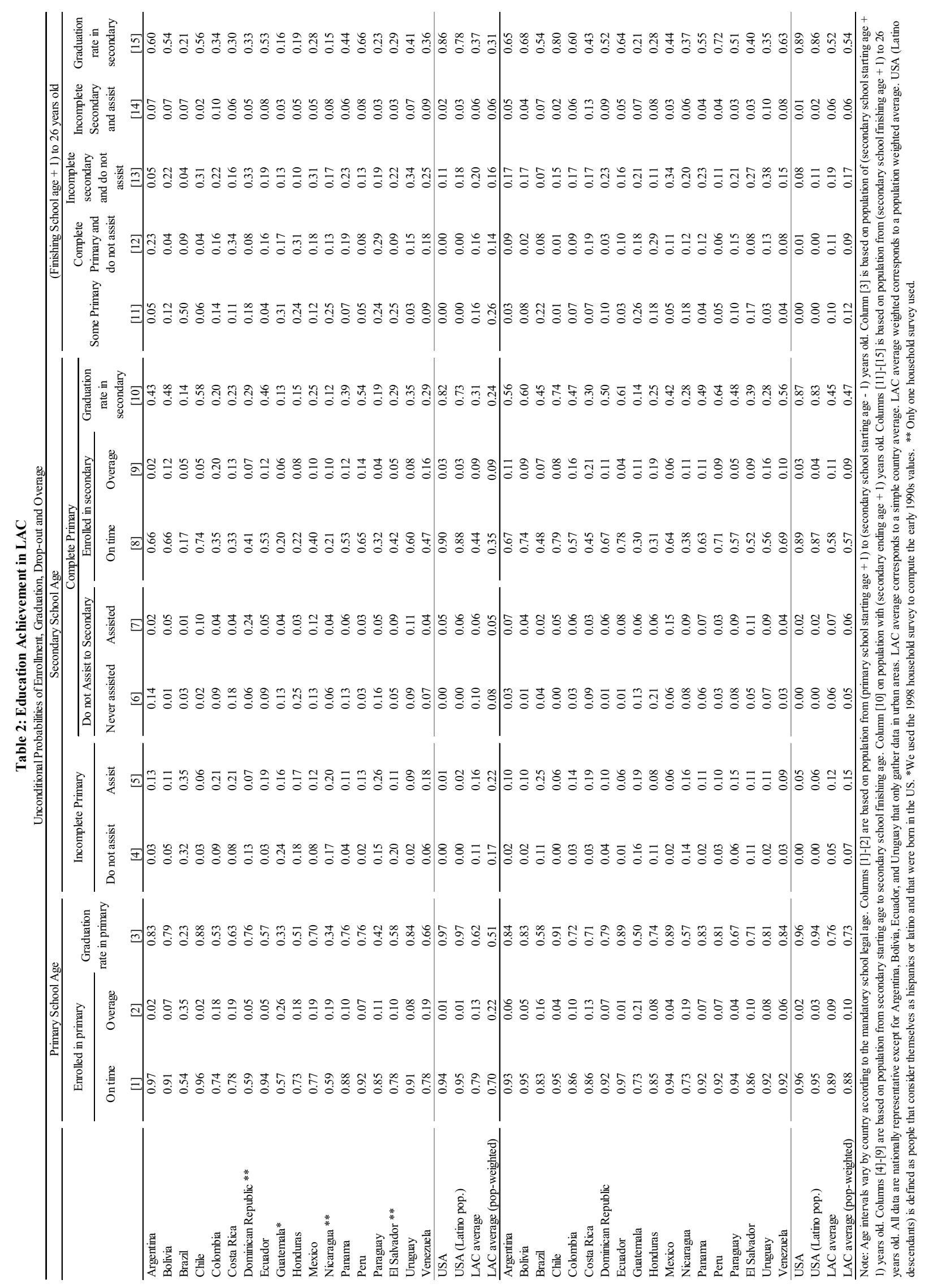


Overall trends are positive in most indicators and in most countries. ${ }^{13}$ In primary school, on-time enrollment increased from 79 percent to 89 percent (column [1]) and overage decreased from 13 percent to 9 percent (column [2]). Graduation rates in primary increased from 62 percent to 76 percent (column [3]). When the regional average is calculated weighting each country by its population, enrollment in primary increased from 70 percent to 88 percent, overage decreased from 22 percent to 10 percent and graduation rate increased from 51 percent to 73 percent. Despite the progress, educational outcomes in the region in primary schooling are still well below levels in the US or compared to the outcomes of Latino descendants living in the US.

The improvement in primary schooling implies that, compared to two decades ago, more LatinAmerican children are now able to start secondary school on time. The percentage of primary graduates that abandon school during the transition to secondary education (i.e. never enroll in secondary school) decreased (column [6]) and primary school graduates that enroll in secondary school but leave before graduating slightly increased (column [7]). This indicates that dropout in secondary school occurs later in the schooling cycle than in the early 1990s. Enrollment on time in secondary school increased from 44 percent to 58 percent (column [8]) and overage remained nearly unchanged (column [9]). The weighted average of enrollment on time in secondary school increased even more, from 35 percent to 57 percent. Graduation rates in secondary school also improved, both among secondary school aged students (column [10]) and among older students (column [15]). Compared to secondary graduation rates in the US (which rank poorly among OECD countries (Murnane, 2013)) and among Latino descendants in the US, Latin America is still lagging behind, although the fast growth in the last two decades helped reducing the gap.

We next extend the analysis of the trends in educational outcomes for secondary schooling in four ways: we analyze the evolution of graduation rates along the last two decades and among birth cohorts, we compare conditional and unconditional rates, we analyze the timing of dropout, and we study changes in educational outcomes by gender, urban-rural areas, and income quintiles.

\footnotetext{
${ }^{13}$ It is important to note that all variables analyzed here (e.g. graduation rates) have a bounded support in $[0,1]$. Therefore, the magnitude of improvements will tend mechanically to decline, exhibiting diminishing marginal improvements.
} 


\subsection{Graduation rate increased}

Our data allows not only for the comparison of educational outcomes between two points in time, but also the analysis of the evolution throughout the period. This exercise helps to understand if the observed changes were the result of a smooth and gradual evolution or if there were clear breaks at some moments in time, presumably responding to specific episodes or policies.

Figure 1 presents the evolution of primary (panel a) and secondary (panel b) graduation rates since the early 1990s, both the regional average (weighted and unweighted) and the individual trends for each country in our sample. Although unconditional graduation rates in primary and secondary school show continuous progress over the two decades, their growth accelerates in the late 1990s.

Figure 1: Graduation Rates Trends (Average LAC)
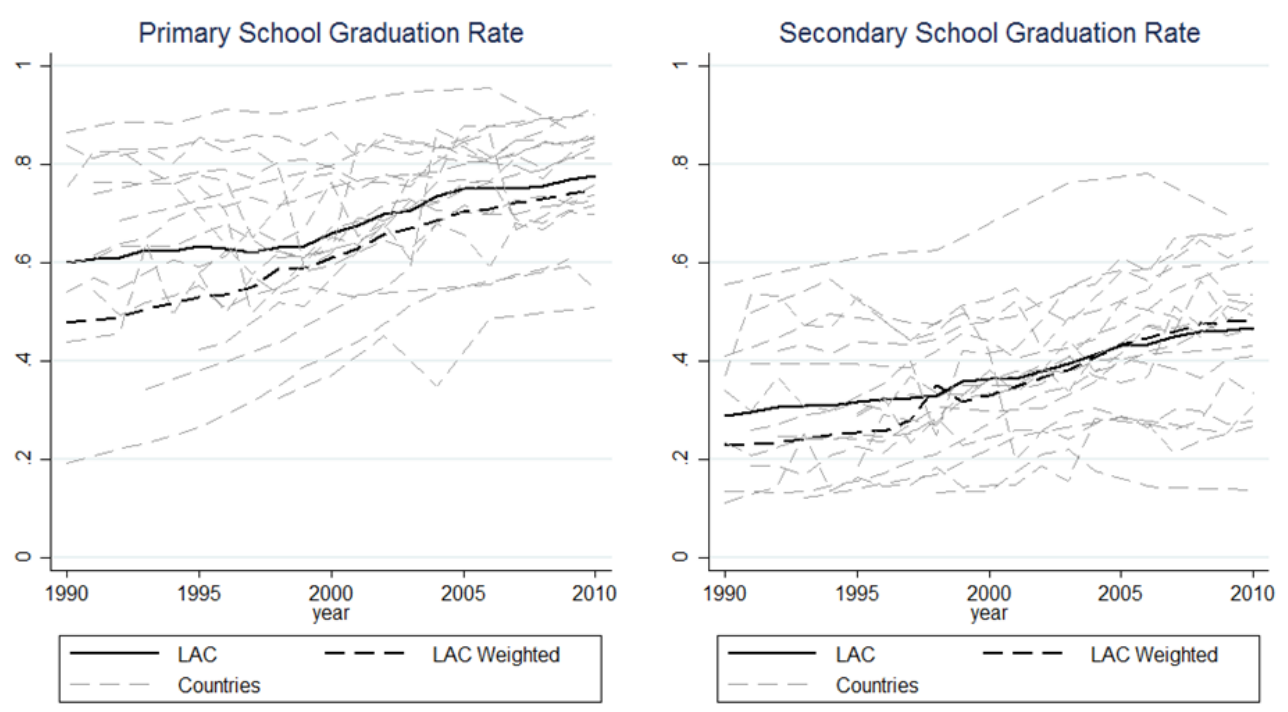

Note: Graduation rate computed on the population with (secondary ending age +1 ) years old. LAC average reports the simple average between the countries. LAC weighted is computed by weighting the average by the countries' population. For the years in which no data was available we computed the mean between the latest and the next available values. If the missing value was not in between two available years then we replaced it by the nearest year.

This growth was more pronounced in larger countries like Brazil and Mexico, as showed in the steeper trend of the average rates weighted by population size. The same pattern is observed disaggregating the average graduation rate by sub-region, namely Southern Cone (Argentina, Brazil, Chile, Paraguay and Uruguay), Andean countries (Bolivia, Colombia, Ecuador, Peru and Venezuela), and Central America and Mexico (Costa Rica, Dominican Republic, El Salvador, 
Guatemala, Honduras, Mexico, Nicaragua, and Panama). The three groups show a faster increase in secondary school graduation rates after the late 1990s (Figure 2, panel a). ${ }^{14}$

Figure 2: Secondary School Graduation Rate Trends
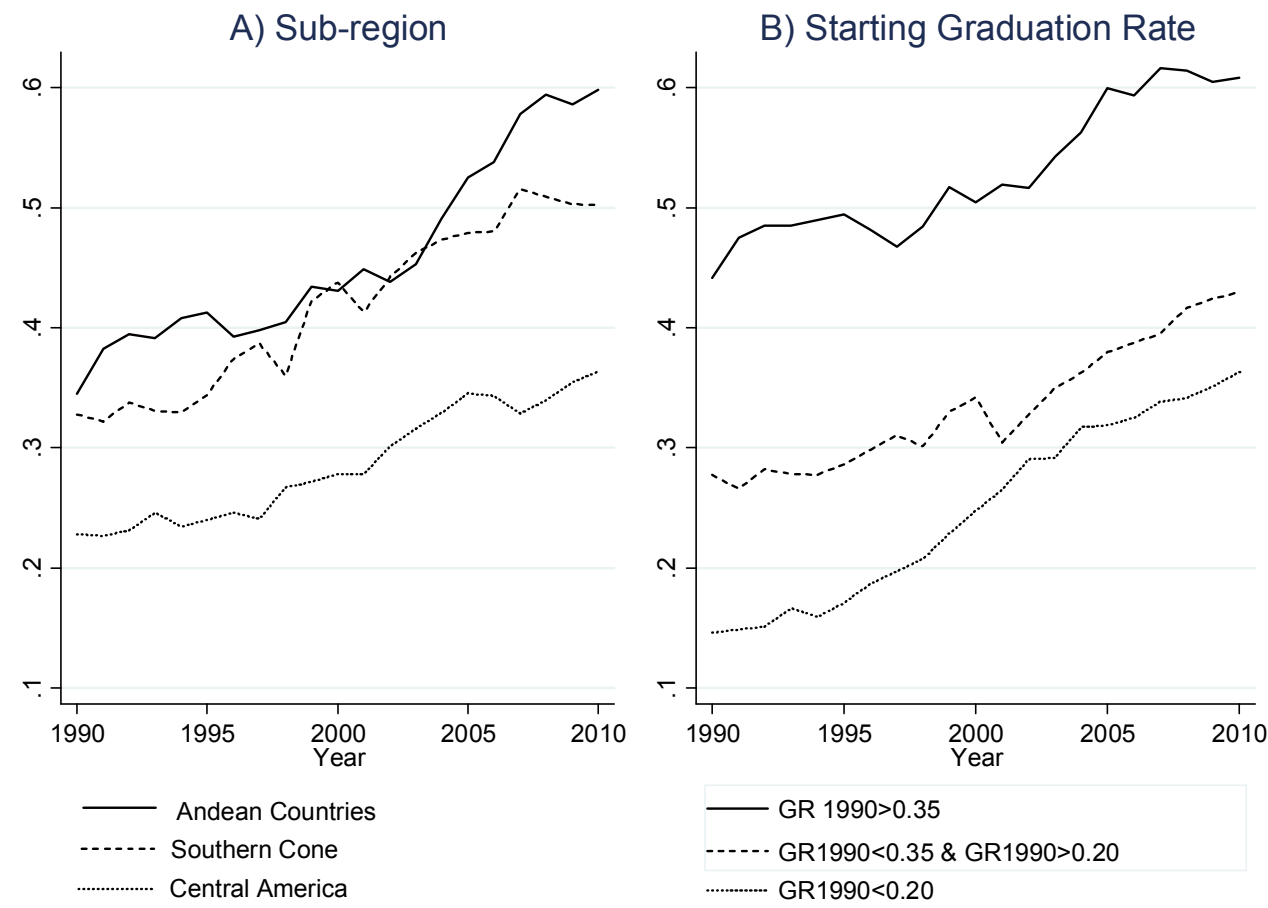

\begin{abstract}
Note: Graduation rate computed on the population with (secondary ending age +1 ) years old. For the years in which no data was available we computed the mean between the latest and the next available values. If the missing value was not in between two available years then we replaced it by the nearest year. The values reported are the simple average between LAC countries. Southern cone includes Argentina, Chile, Uruguay, Paraguay, and Brazil. Andean Community include Colombia, Ecuador, Bolivia, Peru, and Venezuela. Central America is composed by Panama, Costa Rica, Dominican Republic, Guatemala, Honduras, Nicaragua, El Salvador, and Mexico. In the panel B of the graph the group GR(1990)> 0.35 includes: Argentina, Bolivia, Chile, Ecuador, Panama, and Peru. The group with GR(1990)<0.35 and >0.2 includes: Costa Rica, Dominican Republic, Mexico, El Salvador, Uruguay, Venezuela. Finally, the group with GR(1990)<0.2 includes: Brasil, Colombia, Guatemala, Honduras, Niraramı and Paramiav
\end{abstract}

Lastly, our data shows a convergence in graduation rates between countries that started the analyzed period with the lowest levels. Panel $b$ in Figure 2 shows the graduation rate in secondary schooling for three groups of countries according to where they started in the early 1990s. ${ }^{15}$ Between mid-1990s and early 2000s, countries with the lowest graduation rate in

\footnotetext{
${ }^{14}$ In the Andean countries, the break in the trend appears later, in the early 2000s.

${ }^{15}$ The criteria followed was grouping countries with secondary graduation rates below 20 percent in group 1, countries with secondary graduation rates between 20 percent and 35 percent in group 2, and countries with secondary graduation rates above 35 percent in group 3 .
} 
secondary schooling showed the greatest improvements, nearly catching up with the counties in the middle group. The trends of the three groups behave similarly thereafter. ${ }^{16,17}$

In order to provide longer-term trends we look at graduation rates changed by birth cohorts. Figure 3 presents the probability of graduating from primary and secondary schooling for each cohort born since the early twentieth century. It was calculated as the proportion of graduates in each schooling level among those individuals in our sample who were born in the same year (from 1905 to 1983). Even though there is a lot of heterogeneity between the rates observed in each country, the data shows that graduation rates increased constantly for most countries over the period 1930-1980. With only few exceptions among the earliest cohorts, each cohort achieved higher graduation rates than its predecessors. On average, cohorts born between 1940 and 1960, and the latest cohorts (those born between around 1970 and 1983) show the largest improvements.

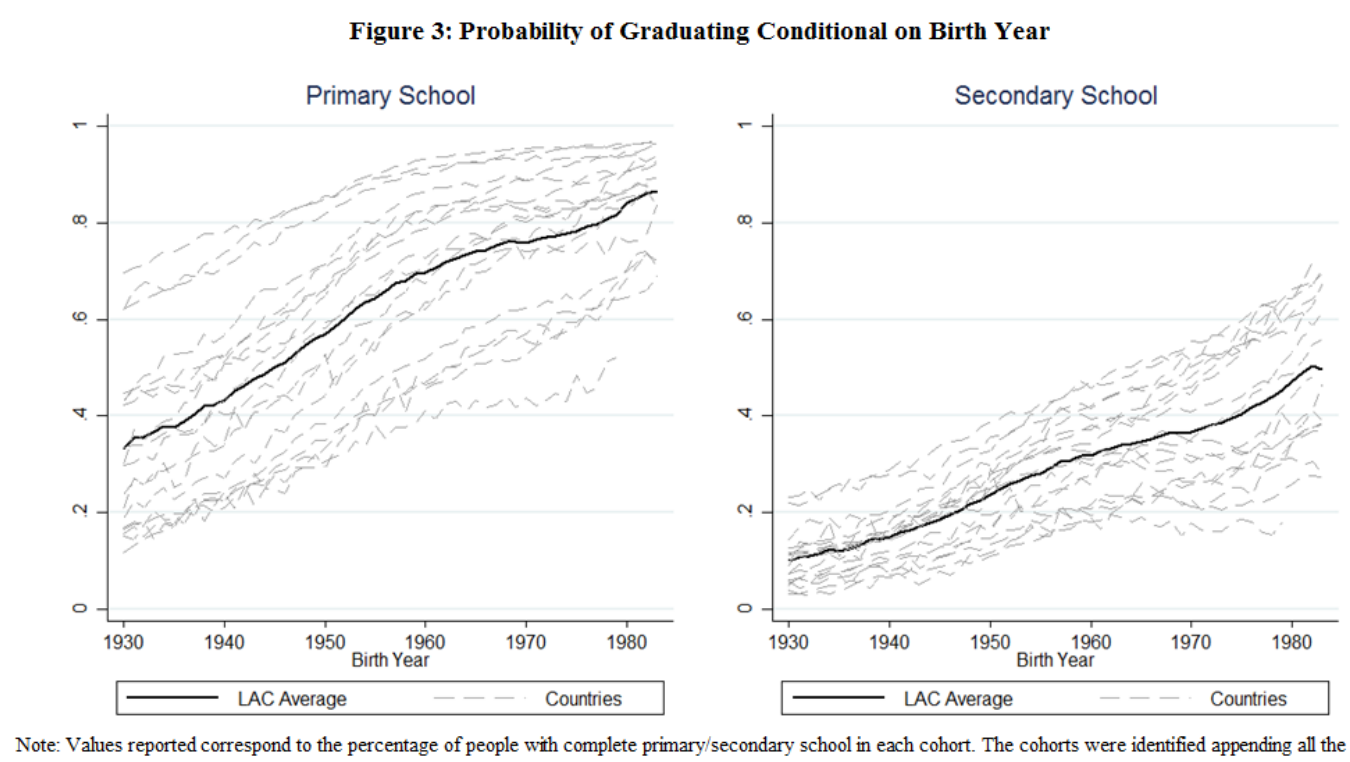
household surveys and computing the individual's birth year. The LAC average is the simple arithmetic mean among the 18 LAC countries

Table 3 shows the changes over 1990-2000 in secondary school educational outcomes following the definitions described in Table 1. Both conditional and unconditional enrollment in secondary schooling increased in almost all countries during the analyzed period. On average the

\footnotetext{
${ }^{16}$ Results are even more pronounced in the case of primary school (see Appendix Figure 1).

${ }^{17}$ Similar patterns are observed in terms of primary graduation rates, both among sub-regions and among countries grouped by their initial level in terms of graduation rate. Figure 1 in the appendix presents this information.
} 
unconditional enrollment rate increased 15 percentage points and the conditional enrollment rate increased 8 percentage points, which indicates that part of the higher unconditional enrollment occurred among individuals that never enrolled in secondary school.

Table 3: Secondary School Enrollment and Graduation Rates

\begin{tabular}{|c|c|c|c|c|}
\hline & \multicolumn{2}{|c|}{ Enrollment } & \multicolumn{2}{|c|}{ Graduation } \\
\hline & $\begin{array}{c}\text { Unconditional } \\
{[1]}\end{array}$ & $\begin{array}{c}\text { Conditional } \\
{[2]} \\
\end{array}$ & $\begin{array}{c}\text { Unconditional } \\
{[3]} \\
\end{array}$ & $\begin{array}{c}\text { Conditional } \\
{[4]}\end{array}$ \\
\hline USA & 0.01 & 0.03 & 0.05 & 0.07 \\
\hline USA (Latino pop.) & 0.00 & 0.04 & 0.10 & 0.14 \\
\hline LAC average & 0.15 & 0.08 & 0.15 & 0.09 \\
\hline LAC average (pop-weighted & 0.23 & 0.08 & 0.23 & 0.15 \\
\hline Argentina & 0.09 & 0.07 & 0.14 & 0.06 \\
\hline Bolivia & 0.06 & 0.02 & 0.15 & 0.13 \\
\hline Brazil & 0.34 & 0.05 & 0.31 & 0.15 \\
\hline Chile & 0.08 & 0.07 & 0.16 & 0.15 \\
\hline Colombia & 0.19 & 0.09 & 0.27 & 0.26 \\
\hline Costa Rica & 0.19 & 0.17 & 0.07 & -0.02 \\
\hline Dominican Republic & 0.30 & 0.31 & 0.21 & 0.19 \\
\hline Ecuador & 0.18 & 0.07 & 0.15 & 0.01 \\
\hline Guatemala & 0.15 & 0.09 & 0.01 & -0.14 \\
\hline Honduras & 0.20 & 0.13 & 0.09 & -0.02 \\
\hline Mexico & 0.19 & 0.10 & 0.18 & 0.11 \\
\hline Nicaragua & 0.18 & -0.01 & 0.16 & 0.14 \\
\hline Panama & 0.09 & 0.08 & 0.10 & 0.05 \\
\hline Peru & 0.00 & -0.01 & 0.10 & 0.12 \\
\hline Paraguay & 0.26 & 0.16 & 0.30 & 0.23 \\
\hline El Salvador & 0.13 & 0.03 & 0.10 & 0.04 \\
\hline Uruguay & 0.04 & 0.05 & -0.06 & -0.09 \\
\hline Venezuela & 0.18 & 0.08 & 0.28 & 0.24 \\
\hline \multicolumn{5}{|c|}{$\begin{array}{l}\text { Note: Computations are based on population from secondary starting age to secondary } \\
\text { school finishing age. Enrollment and graduation - conditional and unconditional - are } \\
\text { computed following the definitions shown on Table } 1 \text {. Early } 1990 \text { s computed for years } \\
1990-1995 \text { and late } 2000 \text { s for } 2005-2010 \text {. Changes by country express the late } \\
2000 \text { s rate minus the early } 1990 \text { s rate. }\end{array}$} \\
\hline
\end{tabular}

The increase in the weighted average enrollment rate was even higher (23 percentage points), largely because of changes in Brazil, which were the greatest in our sample (34 percentage points). Dominican Republic showed the second highest increase in enrollment (30 percentage points in the unconditional rate and 31 percentage points in the conditional rate). In both cases, the unconditional enrollment rate started in relatively low levels (below the Latin American average) in the early 1990s. In Brazil, however, most of the change happened in primary school, as indicated by the smaller increase in the conditional enrollment rate compared to the unconditional enrollment rate. Peru, Bolivia, and Uruguay showed the smallest increase in enrollment in the sample, but all of them started from relatively high levels (compared to the 
Latin American average) in the 1990s. The increase in enrollment in secondary schooling was greater than the change in the US and the change among the Latino descendants in the US. This was expected as we are analyzing a bounded indicator and US was already relatively high at the beginning of the period.

Unconditional high school graduation rates also increased in all countries. On average the unconditional graduation rate in secondary schooling increased 15 percentage points. The weighted average graduation rate increased 23 percentage points, mainly driven by Brazil, which again showed the greatest increase (31 percentage points). Paraguay, Venezuela and Colombia followed with, 30, 28 and 27 percentage points of increase, respectively. Uruguay was the only country in our sample where secondary graduation rates deteriorated and Guatemala remained almost unchanged. The progress in the region in terms of secondary school graduation was higher than in the US and among Latino descendants in the US, which is noteworthy since the US was recovering from a very weak period. Yet, the level of the high school graduation rate in the US is still significantly higher than in Latin America, which clearly limits the potential progress in this bounded indicator.

Conditional graduation rates also increased (both measured by the simple average and the weighted average) showing that the greater proportion of secondary school graduates responds not only to having more youths in school but also to a greater efficiency of the education systems to prevent early dropout. Colombia shows the highest increase in the conditional graduation rate, while Guatemala and Uruguay show significant decreases in this indicator. In the case of Guatemala, as in Costa Rica and Honduras, which also experienced a decrease (although smaller) in the conditional graduation rate in secondary schooling, the slightly higher proportion of secondary school graduates (unconditional rate) is associated to greater enrollment, as will be explained in more detailed in the following section. ${ }^{18}$

\footnotetext{
${ }^{18}$ Dropout and overage rates (both conditional and unconditional, as defined in Table 1) were also estimated. The information is presented in the Appendix (Table 2). Results are also positive, showing a decrease in both dropout and overage rates on average in the region (measured by conditional and unconditional rates, with the only exception of the conditional overage rate, which remained unchanged). Changes were more significant measured by the weighted average for the region. In these two indicators again, Latin America showed better progress (reduction in this case) than the US in the analyzed period.
} 


\subsection{Students drop out later in the schooling cycle}

The fact that both conditional and unconditional graduation rates improved, on average, and that overage decreased, indicates that dropping out might be occurring less in primary school and that students might be staying longer in the education system. Understanding at what stage of the schooling cycle students drop out with the highest probability has important implications for identifying the causes of school abandonment and for designing effective policies to prevent it.

Figure 4 presents the probability completing a certain number of years of education conditional on not having graduated from secondary school. Panel A shows the average for Latin America in the two time periods and for the US in the late 2000s. The curve for the late 2000s for the region is above the curve for the early 1990s, which shows that students now stay longer in school or that dropout happens later in the school cycle. The part of the curve between 0 and 6 years of education is flatter for the late 2000s than for the early 1990s, indicating that a larger fraction of students (that did not complete secondary schooling) completed at least 6 years of education.

Figure 4: Time of Dropout

Probability of achieving $y$ years of education (conditional on not having finished secondary school and not enrolled)
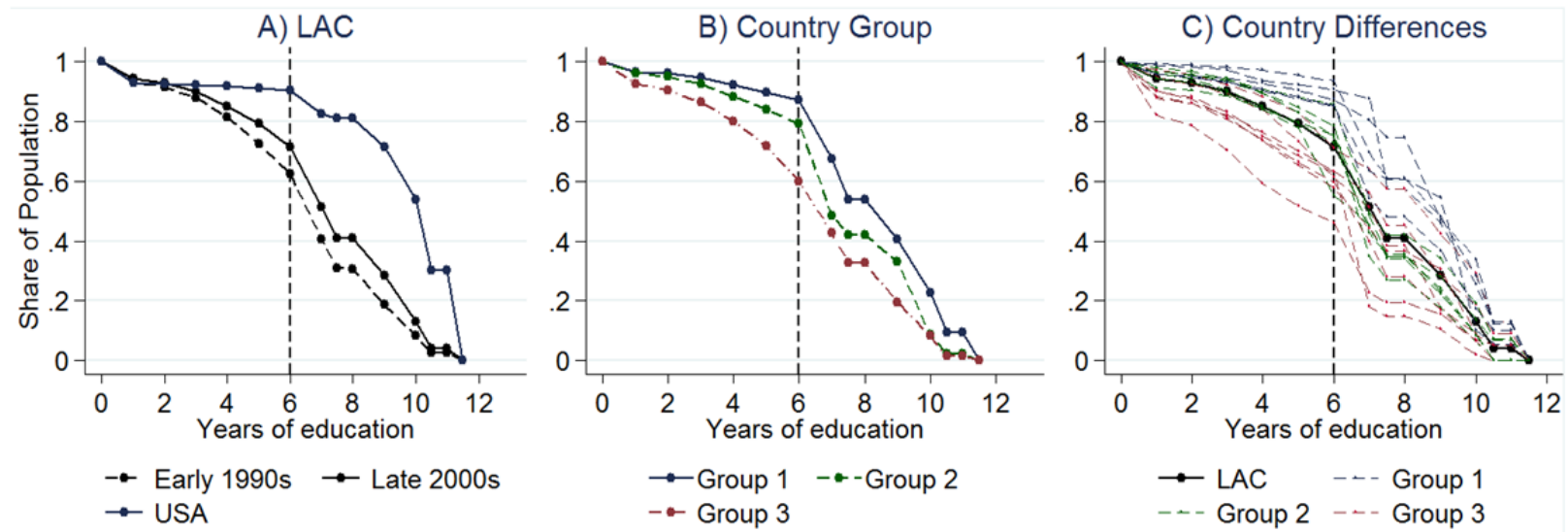

Note: Vahes computed as the percentage of the population with Y years of education. Only population with no secondary school and not assisting to school used. Early 1990s computed for years 1990-1995 and late 2000s for 2005-2010. Rural-Urban and Male-Female identified by data provided in each survey. Income quintiles constructed using the primary and secondary activity household (winsorized) wages. Countries divided by the percentage of people dropping out by the 6 th year of education.Type $1=$ dropped less than $20 \%$ of people. Type $2=$ dropped between 20 and $30 \%$. Type $3=$ more than $30 \%$. Country group 1 formed by Argentina, Chile, Ecuador, Panama, Uruguay, Venezuela. Country group 2 formed by Costa Rica, Mexico, Peru. Country group 3 formed by Bolivia, Brasil, Colombia, Dominican Republic, Guatemala, Honduras, Nicaragura, Paraguay, and El Salvador.

The curve for the US shows that dropout occurs almost entirely in high school, especially during the last two years of high school. Panels B and C in Figure 4 again distinguish the three groups of countries. Most dropouts in Group 1 (Argentina, Chile, Ecuador, Panama, Uruguay and 
Venezuela) occurred during secondary (particularly in early secondary). Only 12 percent of students that dropped out of school in these countries did so during primary or in the transition to secondary school in the late 2000s. However, this is not true in the other countries, where a larger proportion of dropouts leave the school system in the late primary or in the transition between primary and secondary school. In Group 2 (Costa Rica, Mexico and Peru) almost one third of the dropouts happen in the transition to secondary school and in Group 3 (Bolivia, Brazil, Colombia, Dominican Republic, Guatemala, Honduras, Nicaragua, Paraguay and El Salvador) around 40 percent of dropouts happen in primary school. Panel C shows that these patterns in fact hide a significant country-level variation. ${ }^{19}$

\subsection{Gender, regional and income achievement gaps within countries did not close}

Table 4 shows the average gap in secondary school graduation rates for different groups of people (by gender, region, or income). Latin American women, for example, achieve a higher graduation rate than men and that gap has increased over the last two decades (from 5 percentage points to 8 percentage points measured by the unconditional graduation rate and 4 percentage points to 7 percentage points measured by the conditional graduation rate). The increase in the gender gap in graduation rates is observed in most countries in our sample (exceptions are Argentina, Colombia, Ecuador, Peru and El Salvador) and for both the weighted and unweighted regional average. These results contrast with those for the US, where the gap was reduced 2 percentage points on average and 1 percentage point among the Latino population. Except for the last few years (after 2005), when there seems to be an increase in the gap because graduation among men stagnated, the trends observed for men and women are almost parallel, with women graduation in higher (and relatively stable) proportions than men. ${ }^{20}$

Schools in rural areas show considerable lower graduation rates than schools in urban areas and that gap remained almost constant (or decreased slightly). When the regional average is computed using population weights, the gap in the unconditional graduation rate shows an

\footnotetext{
${ }^{19}$ Appendix Table 3 presents further details that complement and expand the results presented in Figure 4.

${ }^{20}$ Results shown in Appendix Figure 2. The Appendix includes the same analysis for primary school graduation rates, comparing their evolution by gender, regional area and income level (Figures 3 and 4). Results are similar than those observed in secondary schooling.
} 
increase of 5 percentage points, mainly driven by Brazil and Colombia. Although the average for the region shows no (or little) improvement, five countries in our sample (Chile, Costa Rica, Dominican Republic, Peru and El Salvador) could reduce the urban-rural gap in graduation rates over the last two decades. The US shows improvement in this indicator, reducing the gap between rural and urban areas by around 6 percentage points (and 3 percentage points among Latino descendants).

Table 4: Change in Secondary School Graduation Gaps

\begin{tabular}{|c|c|c|c|c|c|c|}
\hline & \multicolumn{2}{|c|}{ Female-Male } & \multicolumn{2}{|c|}{ Urban-Rural } & \multicolumn{2}{|c|}{ Quntile 5- Quintile 1 } \\
\hline & Unconditional & Conditional & Unconditional & Conditional & Unconditional & Conditional \\
\hline & {$[1]$} & [2] & {$[3]$} & {$[4]$} & {$[5]$} & [6] \\
\hline LAC early $1990 \mathrm{~s}$ & 0.05 & 0.04 & 0.24 & 0.21 & 0.29 & 0.24 \\
\hline LAC late $2000 \mathrm{~s}$ & 0.08 & 0.07 & 0.24 & 0.19 & 0.35 & 0.30 \\
\hline LAC change & 0.04 & 0.04 & 0.00 & -0.02 & 0.06 & 0.06 \\
\hline LAC change pop-weighted & 0.04 & 0.01 & 0.05 & 0.00 & 0.11 & 0.08 \\
\hline \multicolumn{7}{|l|}{ Change by country } \\
\hline Argentina & -0.05 & -0.10 & - & - & 0.01 & 0.05 \\
\hline Bolivia & 0.01 & -0.02 & - & - & 0.08 & 0.14 \\
\hline Brazil & 0.08 & 0.02 & 0.13 & 0.00 & 0.24 & 0.11 \\
\hline Chile & 0.05 & 0.07 & -0.27 & -0.25 & -0.03 & 0.01 \\
\hline Colombia & -0.01 & -0.04 & 0.12 & 0.12 & 0.19 & 0.18 \\
\hline Costa Rica & 0.03 & 0.00 & -0.14 & -0.16 & 0.09 & 0.14 \\
\hline Dominican Republic & 0.17 & 0.17 & -0.05 & -0.11 & -0.09 & -0.17 \\
\hline Ecuador & -0.03 & -0.04 & - & - & 0.17 & 0.18 \\
\hline Guatemala & 0.06 & 0.17 & -0.06 & 0.03 & 0.02 & 0.11 \\
\hline Honduras & 0.05 & 0.07 & 0.08 & 0.07 & 0.16 & 0.21 \\
\hline Mexico & 0.02 & -0.01 & -0.02 & 0.02 & -0.01 & 0.03 \\
\hline Nicaragua & 0.13 & 0.26 & 0.10 & 0.03 & -0.03 & -0.22 \\
\hline Panama & 0.01 & 0.02 & 0.08 & 0.07 & 0.05 & 0.10 \\
\hline Peru & -0.03 & -0.06 & -0.01 & -0.06 & 0.12 & 0.12 \\
\hline Paraguay & 0.08 & 0.07 & 0.09 & 0.01 & -0.04 & -0.11 \\
\hline El Salvador & -0.01 & -0.03 & -0.04 & -0.03 & 0.06 & 0.09 \\
\hline Uruguay & 0.07 & 0.09 & - & - & 0.15 & 0.20 \\
\hline Venezuela & 0.03 & 0.02 & - & - & -0.11 & -0.06 \\
\hline USA & -0.02 & -0.02 & -0.06 & -0.06 & -0.03 & -0.05 \\
\hline USA (latino pop.) & -0.01 & -0.01 & -0.03 & -0.04 & -0.08 & -0.11 \\
\hline
\end{tabular}

Note: Computations are based on population from secondary school starting age to secondary school finishing age. Graduation rates - conditional and unconditional - are computed following the definitions shown on Table 1 .Early 1990s computed for years 1990-1995 and late 2000s for 2005-2010. Changes by country express the 2010 rate minus the 1990 rate. Rural-Urban and Male-Female identified by data provided in each survey. Income quintiles constructed using the primary and secondary activity household (winsorized) wages.

The secondary school graduation gap between populations in different income quintiles also shows little improvement. Students from the highest income quintile have a secondary school unconditional graduation rate 35 percentage points higher than students from the lowest income quintile (and 30 percentage points higher in terms of the conditional rate). This gap increased around 6 percentage points since the early 1990s (both the conditional and unconditional rates). 
On the one hand, graduation among students from the richest families increased steadily since the beginning of 1990 and the growth accelerated in the early 2000s. On the other hand, graduation among students from the lowest income families remained stagnant until the mid2000 s and started growing only thereafter. ${ }^{21}$

In fact, most countries showed an increase in the graduation gap between income quintiles. In Brazil, for example, where as described above remarkable improvements were made in terms of enrollment and graduation rates, the graduation gap between the highest and lowest income students increased by 24 percentage points, indicating that the benefits mainly affected the richest groups. The gap in the conditional graduation rate also increased but less (11 percentage points), which shows that the education system in Brazil has been somewhat more efficient in preventing dropouts among high and low income students once enrolled in secondary school, but quite inefficient in attracting students from lower income families to the secondary education system (at least relative to the changes observed among students from higher income families). Dominican Republic, Nicaragua, Paraguay and Venezuela were able to reduce the graduation gap among income quintiles (in both conditional and unconditional graduation rates). In the same period, the graduation gap between the highest and lowest income quintile in the US was reduced, both on average and among Latino descendants.

\section{Explanations}

We start by decomposing the change in secondary school graduation rates in multiple components that can shed light into what part of the education system contributed more to the positive trend. Then we assess whether changes in the incentives to study provided by the labor market or the introduction of certain policies are correlated with those changes.

\subsection{Graduation rate decomposition}

The probability of graduating from secondary school on time can be expressed as the product of conditional and unconditional probabilities defined in Table 1. That is,

\footnotetext{
${ }^{21}$ See Appendix Figure 4
} 


$$
P\left(G_{s}\right)=P\left(G_{s} \mid E_{s}\right) \times P\left(E_{s} \mid G_{p}\right) \times P\left(G_{p} \mid E_{p}\right) \times P\left(E_{p}\right)
$$

where $P(\cdot)$ is a probability function, $G_{j}$ denotes the event of graduation from school level $j=\{$ primary $(p)$ or secondary $(s)\}$, and $E_{j}$ denotes the event of enrollment. Following Heckman and Lafontaine (2010) we can decompose the change in secondary school graduation rate $\Delta P(G s)$ into the following components: $:^{22}$

$$
\Delta P(G s)=T_{1} \Delta P\left(G_{s} \mid E_{s}\right)+T_{2} \Delta P\left(E_{s} \mid G_{p}\right)+T_{3} \Delta P\left(G_{p} \mid E_{p}\right)+T_{4} \Delta P\left(E_{p}\right)+T_{5}
$$

Table 5 shows the result of this decomposition. The first column shows the total change in secondary school graduation rate while columns [2]-[6] show each one of the five terms in the decomposition.

More students are now eligible to attend secondary school- . The increase in enrollment rate in primary schools partly explains the increase over the last two decades in secondary school graduation rate (as showed in Columns 4 and 5 of Table 5). On average 35 percent (5 out of 15 percentage points) of the increase in graduation of secondary school was explained by improvements in primary school. This pattern holds for most countries including Ecuador, Brazil, El Salvador, Costa Rica, Nicaragua, Honduras and Mexico.

Indeed, countries with the greatest secondary school graduation rate increases (for example, Brazil, Colombia or Venezuela) also show the greatest increases in primary school graduation rates, and countries with the lowest increases in secondary school graduation rates (Uruguay or Chile) show the same patterns in primary education. In other words, achieving the first milestone in primary school necessarily led more students to be ready for secondary education, having a cascade effect in secondary school.

The efficacy of secondary school increased - Another important fact to explain the increase in secondary school graduation rates is that secondary schools in the region have become more effective in two dimensions: capturing and graduating their students.

${ }^{22} T_{1}=P\left(E_{s} \mid G_{p}\right) P\left(G_{p} \mid E_{p}\right) P\left(E_{p}\right), T_{2}=P\left(G_{s} \mid E_{s}\right) P\left(G_{p} \mid E_{p}\right) P\left(E_{p}\right), T_{3}=P\left(G_{s} \mid E_{s}\right) P\left(E_{s} \mid G_{p}\right) P\left(E_{p}\right), T_{4}=$ $P\left(G_{s} \mid E_{s}\right) P\left(E_{s} \mid G_{p}\right) P\left(G_{p} \mid E_{p}\right)$ and $T_{5}=F\left[G_{j}, E_{j}\right], F($.$) is a cross-product function composed by the sum of all the$ possible combinations of probabilities and changes. For computations, levels are fixed at those of the first year in the sample. 
Table 5: Changes in Graduation Rates in LAC

Conditional Probabilities

\begin{tabular}{|c|c|c|c|c|c|c|}
\hline & \multicolumn{6}{|c|}{ Secondary School Age } \\
\hline & $\begin{array}{c}\Delta \mathrm{P}(\mathrm{Gs}) \\
{[1]} \\
\end{array}$ & $\begin{array}{c}\Delta \text { due to } \\
\mathrm{P}(\mathrm{Gs} \mid \mathrm{Es}) \\
{[2]}\end{array}$ & $\begin{array}{c}\Delta \text { due to } \\
\mathrm{P}(\mathrm{Es} \mid \mathrm{Gp}) \\
{[3]}\end{array}$ & $\begin{array}{c}\Delta \text { due to } \\
\text { P(Gp | Ep) } \\
{[4]}\end{array}$ & $\begin{array}{c}\Delta \text { due to } \\
\mathrm{P}(\mathrm{Ep}) \\
{[5]}\end{array}$ & $\begin{array}{c}\Delta \text { due to } \\
\text { interactions } \\
{[6]}\end{array}$ \\
\hline Argentina & 0.14 & 0.04 & 0.06 & 0.02 & 0.00 & 0.01 \\
\hline Bolivia & 0.12 & 0.09 & 0.00 & 0.02 & 0.00 & 0.01 \\
\hline Brazil & 0.31 & 0.03 & 0.01 & 0.18 & 0.01 & 0.08 \\
\hline Chile & 0.16 & 0.13 & 0.01 & 0.01 & 0.00 & 0.00 \\
\hline Colombia & 0.27 & 0.15 & 0.02 & 0.04 & 0.00 & 0.06 \\
\hline Costa Rica & 0.07 & -0.01 & 0.05 & 0.03 & 0.00 & 0.00 \\
\hline Dominican Republic & 0.21 & 0.14 & 0.02 & 0.02 & 0.00 & 0.02 \\
\hline Ecuador & 0.15 & 0.01 & 0.05 & 0.08 & 0.00 & 0.01 \\
\hline Guatemala & 0.01 & -0.04 & 0.02 & 0.03 & 0.02 & -0.01 \\
\hline Honduras & 0.10 & -0.01 & 0.04 & 0.04 & 0.01 & 0.01 \\
\hline Mexico & 0.18 & 0.07 & 0.03 & 0.04 & 0.01 & 0.03 \\
\hline Nicaragua & 0.16 & 0.05 & 0.00 & 0.04 & 0.03 & 0.04 \\
\hline Panama & 0.10 & 0.04 & 0.04 & 0.01 & 0.00 & 0.01 \\
\hline Peru & 0.10 & 0.10 & 0.00 & 0.01 & 0.00 & 0.00 \\
\hline Paraguay & 0.29 & 0.09 & 0.05 & 0.07 & 0.00 & 0.09 \\
\hline El Salvador & 0.10 & 0.02 & 0.01 & 0.05 & 0.02 & 0.01 \\
\hline Uruguay & -0.06 & -0.07 & 0.01 & 0.00 & 0.00 & 0.00 \\
\hline Venezuela & 0.28 & 0.16 & 0.02 & 0.05 & 0.00 & 0.04 \\
\hline USA & 0.05 & 0.08 & 0.00 & -0.03 & 0.00 & 0.00 \\
\hline USA (latino pop.) & 0.10 & 0.12 & 0.00 & -0.01 & 0.00 & 0.00 \\
\hline LAC average & 0.15 & 0.06 & 0.03 & 0.04 & 0.01 & 0.02 \\
\hline LAC average (pop-weighted) & 0.22 & 0.07 & 0.02 & 0.08 & 0.01 & 0.05 \\
\hline $\begin{array}{l}\text { Note: Columns express the term } \\
\text { secondary graduation rate betw } \\
\left.\mathrm{Gp})^{*} \mathrm{P}(\mathrm{Gp} \mid \mathrm{Ep}) * \mathrm{P}(\mathrm{Ep})\right] \text {. Colum } \\
\text { equal to }\left[\mathrm{P}(\mathrm{Gs} \mid \mathrm{Es}) * \mathrm{P}(\mathrm{Es} \mid \mathrm{Gp})^{*}\right. \\
\left.\mathrm{Ep})^{*} \Delta \mathrm{P}(\mathrm{Ep})\right] \text {. Column }[6] \text { is eq } \\
\text { use population from secondary }\end{array}$ & $\begin{array}{l}\text { in the dec } \\
\text { en early } 19 \\
\mathrm{~S}[3] \text { is equ } \\
\mathrm{P}(\mathrm{Gp} \mid \mathrm{Ep}) \\
\text { al to the su }\end{array}$ & $\begin{array}{l}\text { omposition o } \\
990 \text { 's and late } \\
\text { ual to }[\mathrm{P}(\mathrm{Gs} \mid \mathrm{E} \\
* \mathrm{P}(\mathrm{Ep})] . \mathrm{Co} \\
\text { um of the res }\end{array}$ & $\begin{array}{l}\Delta \mathrm{P}(\mathrm{Gs}) \text {. Colt } \\
2000 \text { 's. Colun } \\
\mathrm{s}) * \Delta \mathrm{P}(\mathrm{Es} \mid \mathrm{G} \\
\mathrm{umns}[5] \text { is eq } \\
\text { of the terms }\end{array}$ & $\begin{array}{l}\text { umn [1] show } \\
\mathrm{nn}[2] \text { is equal } \\
\mathrm{p})^{*} \mathrm{P}(\mathrm{Gp} \mid \mathrm{Ep}) \\
\text { ual to }[\mathrm{P}(\mathrm{Gs} \mid \mathrm{I} \\
\text { in the decomp }\end{array}$ & $\begin{array}{l}\text { the chang } \\
\mathrm{o}[\Delta \mathrm{P}(\mathrm{Gs} \\
\mathrm{P}(\mathrm{Ep})] . \mathrm{C} \\
\text { )*P(Es } \\
\text { sition. Co }\end{array}$ & $\begin{array}{l}\text { in the } \\
\text { Es)*P(Es | } \\
\text { lumns [4] is } \\
\text { sp)*P(Gp | } \\
\text { Imns [1]-[6] }\end{array}$ \\
\hline
\end{tabular}

As column [3] of Table 5 shows, about 17 percent ( 3 out of 15 percentage points) of the improvement in secondary school graduation is explained by the fact that secondary schools in the region are able to capture a larger proportion of students that finish primary school. This explanation is particularly important in Argentina, Ecuador, and Costa Rica.

More importantly, however, has been the increase in efficacy of secondary schools to retain and graduate students. Column [2] of Table 5 shows that on average 38 percent (6 out of 15 percentage points) of the change in secondary school graduation rates was due primarily to this factor. In Chile and Peru increased efficacy explains more than 80 percent of the increase in their secondary school graduation rates. On the other end of the spectrum, Ecuador and Costa Rica show a decline in the capacity to keep student in school. 


\subsection{Labor market incentives}

Several studies analyze both the causal impact of observed as well as perceived positive returns to education on enrollment and graduation. For instance, Foster and Rosenszweig (1996) use an exogenous technical change in India which led to higher primary school returns that resulted in higher levels of schooling. Jensen (2012) provided labor market opportunities for women in randomly selected rural Indian villages and concluded that increased labor access has positive effects on schooling. In addition, some studies found that if the returns for unskilled labor (workers with less than completed secondary school education) increased then the students have more incentives to drop out (Foster and Rosenszweig, 2004; Black et al., 2005; Edmonds et al., 2010).

Perceived returns also seem to matter. Jensen (2010) conducted a survey experiment on 8th graders in the Dominican Republic and found that students who randomly received information about higher returns to education completed 0.20-0.35 more years of schooling. Eckstein and Wolpin (1999) estimated a structural model of high school attendance and work decisions. They conclude that students who drop out of high school were the less motivated and had lower expectations about the rewards of education. Dinkelman and Martínez (2014) found in a recent experiment in Chile a causal relationship between providing children with information about college financial aid and secondary school enrollment. In this case, students decided to study because they perceive a concrete possibility to enroll in tertiary education, and this encouraged them to graduate from secondary school.

We exploit the longitudinal structure of our data to study whether groups that faced better incentives from the labor market experienced larger graduation rates. We construct groups $(g)$ of people according to their income quintiles, gender, and whether they live in rural/urban areas. ${ }^{23}$ We assume the following data generating process:

$$
G R_{g c t}^{S}=\alpha+\theta_{1} U_{g c t}+\theta_{2} W_{g c t}+\mu_{c t}+\varepsilon_{g c t}
$$

\footnotetext{
${ }^{23}$ A group is, for instance, all females living in household whose per capita income is in the first quintile and located in rural areas of country $\mathrm{j}$ in year t. Because some cells are small we discard groups with fewer than 20 average annual observations. We linearly interpolate the values for those years in which we do not have individual level data.
} 
where $G R_{g c t}^{S}$ is the secondary school graduation rate on time in of people who are close to the graduation age (17-18 years old) in group g, in country c, in year $t$. These individuals are not yet in the labor market. When making the decision about whether to finish secondary school or not they observe the labor market performance of similar individuals (i.e. in the same group g) in terms of their unemployment and the wages they earned. $U_{g c t}$ is the unemployment rate of individuals in group $\mathrm{g}$ but who are older. We consider the unemployment rates of four sets of reference workers (and its average): 19-26 years old who have completed secondary school, 1926 years old who have completed tertiary school, 27-55 years old with complete secondary school, and 27-55 years old with complete tertiary school. ${ }^{24}$ Similarly, we computed the mincerian wage returns for those four sets of workers and its average $\left(W_{g c t}\right)$. In the model we include country-year fixed effect $\left(\mu_{c t}\right) . \varepsilon_{g c t}$ is the error term.

If students that are currently in secondary school decide to stay in school rather than dropping out before graduation they are likely to increase unemployment and reduce wages of those reference individuals. Therefore, the OLS estimate of $\theta_{1}$ is biased towards finding a negative correlation and that of $\theta_{2}$ is biased towards finding a positive correlation. To ameliorate this problem we instrument the unemployment rate and the wage returns with its lagged values $\left(U_{g c t-2}, W_{g c t-2}\right)$. It is worth noting that with our data and with this empirical strategy we cannot establish causality. There are omitted factors that could jointly affect graduation and labor market outcomes of these groups. The best we can do is to establish an indicative correlation (or lack thereof). We cluster our standard errors at the country level.

Table 6 presents the results. The first column shows results using average unemployment and wage returns across the three reference groups while columns 2-5 show results using one reference group at a time. We find a positive relation between labor market returns and secondary school graduation while the correlation between the unemployment rate and graduation is negative but not statistically significant for some of the reference groups. In other words, groups that faced better labor market outcomes for secondary school graduates tend to

\footnotetext{
${ }^{24}$ Strictly speaking, this refers to students who are (legal secondary school graduation age +1 ) years old.
} 
have a higher graduation rate, which is consistent with the conjecture that the labor market provides incentives to stay in school. ${ }^{25}$

Table 6: Graduation Rates and Labor Market Outcomes

\begin{tabular}{|c|c|c|c|c|c|}
\hline \multirow{3}{*}{$\begin{array}{l}\text { Secondary School } \\
\text { Graduation Rates as } \\
\text { Dependent Variable }\end{array}$} & \multirow{3}{*}{$\begin{array}{c}\text { Average } \\
\text { Reference } \\
\text { Group }\end{array}$} & \multicolumn{2}{|c|}{ Reference Group: 19-26 } & \multicolumn{2}{|c|}{ Reference Group: 27-55 } \\
\hline & & $\begin{array}{c}\text { Secondary School } \\
\text { Graduates }\end{array}$ & $\begin{array}{c}\text { Tertiary School } \\
\text { Graduates }\end{array}$ & $\begin{array}{c}\text { Secondary School } \\
\text { Graduates }\end{array}$ & $\begin{array}{c}\text { Tertiary School } \\
\text { Graduates }\end{array}$ \\
\hline & & [2] & [3] & [4] & [5] \\
\hline Returns & $\begin{array}{c}0.351 * * * \\
{[0.000]}\end{array}$ & $\begin{array}{c}0.024 \\
{[0.660]}\end{array}$ & $\begin{array}{c}0.195 * * * \\
{[0.001]}\end{array}$ & $\begin{array}{c}0.186^{* * *} \\
{[0.000]}\end{array}$ & $\begin{array}{c}0.259 * * * \\
{[0.000]}\end{array}$ \\
\hline Unemployment & $\begin{array}{l}-0.080 \\
{[0.318]}\end{array}$ & $\begin{array}{c}0.015 \\
{[0.921]}\end{array}$ & $\begin{array}{l}-0.120 * \\
{[0.057]}\end{array}$ & $\begin{array}{l}-0.131 * \\
{[0.055]}\end{array}$ & $\begin{array}{c}-0.107 * * \\
{[0.039]}\end{array}$ \\
\hline Constant & $\begin{array}{c}0.405 * * * \\
{[0.000]}\end{array}$ & $\begin{array}{c}0.523 * * * \\
{[0.000]}\end{array}$ & $\begin{array}{c}0.480 * * * \\
{[0.000]}\end{array}$ & $\begin{array}{c}0.483 * * * \\
{[0.000]}\end{array}$ & $\begin{array}{c}0.394 * * * \\
{[0.000]}\end{array}$ \\
\hline $\begin{array}{l}\text { Observations } \\
\text { R-squared }\end{array}$ & $\begin{array}{l}5,505 \\
0.457\end{array}$ & $\begin{array}{l}5,505 \\
0.408\end{array}$ & $\begin{array}{l}5,501 \\
0.391\end{array}$ & $\begin{array}{l}5,505 \\
0.436\end{array}$ & $\begin{array}{l}5,501 \\
0.438\end{array}$ \\
\hline Country-Year FE & $\mathrm{X}$ & $\mathrm{X}$ & $\mathrm{X}$ & $\mathrm{X}$ & $\mathrm{X}$ \\
\hline \multicolumn{6}{|c|}{$\begin{array}{l}\text { Note: The dependent variable is the graduation rate for individuals that are (final graduation age }+1 \text { ) years old in a cell } \\
\text { defined as the intersection of country, year, gender, income quantile, rural/urban. Wage return refers to the standard } \\
\text { mincerian return to education adjusted by age. Column [1] uses the averages between columns [2]-[5]. Column [2] uses } \\
\text { the returns to secondary school education in the } 19-26 \text { y.o. group, and the unemployment rate of people with incomplete } \\
\text { secondary school in the same age range. Column [3] uses the returns to tertiary school education in the 19-26 y.o. group, } \\
\text { and the unemployment rate of people with complete secondary school in the } 27-55 \text { group. Column [4] uses the returns to } \\
\text { secondary school education in the } 27-55 \text { y.o. group, and the unemployment rate of people with complete tertiary school in } \\
\text { the same age range. Finally, column [5] uses the returns to tertiary school education in the } 27-55 \text { y.o. group, and the } \\
\text { unemployment rate of people with complete tertiary school in the same age range. The regressors were instrumented by } \\
\text { the variable values lagged one period. The only control is a dummy for imputation data. All estimations include country- } \\
\text { year fixed effects and standard errors clustered at the country level. P-values reported in brackets. } * * * p<0.01, * * \\
p<0.05, * p<0.1\end{array}$} \\
\hline
\end{tabular}

\subsection{Public policies}

In the last two decades countries have introduced a number of public policies that could have affected the incentives of students to stay in school. These policies affect both the demand of schooling, including conditional cash transfer programs (CCTs) and changes to the mandatory years of education, as well as the supply of schooling, including increases in government

\footnotetext{
${ }^{25}$ Gasparini et al. (2011) show that the average returns to secondary education fell during the last two decades. During the 2000s there was a reversal in the increase in the returns to tertiary education previously identified in the literature (Manacorda et al. (2010)). They argue that trend there was a reversal in labor demand in the 2000s partially due to a boom in commodity prices that favored the unskilled (non-tertiary educated) workforce.
} 
spending per student, decentralization of the school system to state or local governments, and the introduction of two cycles in the secondary school. ${ }^{26}$

Not all countries introduced all these policies simultaneously. There is both cross-country and time-series variation that can be exploited to estimate correlations between these policies and the graduation rates of secondary school. We assume the following data generating process:

$$
\Delta G R_{c t}^{s}=\gamma+\delta_{1} P_{c t}+\delta_{2} X_{c t}+v_{c}+\xi_{c t}
$$

where $\Delta G R_{c t}^{S}$ is the annual change in (on-time) secondary school graduation rate, $P_{c t}$ is a vector of policy variables, $X_{c t}$ is a vector of control variables, $v_{c}$ are country fixed effect and $\xi_{c t}$ the error term. Our standard errors are clustered by country allowing for arbitrary time correlations in the error terms within each country.

The vector $P_{c t}$ includes a dummy variable that indicates if country $c$ has introduced a conditional cash transfer program (CCT) in year $t$, the log of education expenditure over GDP, a dummy variable that indicates whether the country decentralized its school system, a dummy variable that measures if the country extended the compulsory years of schooling, a dummy variable if the country change their secondary school from one 5 year cycle to two cycles of three years each (lower and upper/high/preparatory school). The vector $X_{g c t}$ includes several control variables: the annual change in (on-time) primary school graduation rates, dummies for changes in questionnaires and interpolation dummies. Results are presented in Table 7.

There was an expansion over the last 20 years of CCTs programs in the region. These programs transfer cash to families and require in exchange that children are enrolled and attend school. We find that overall the effect of CCTs was small. However, CCTs seem to have increased graduation rates among students who live in poor households and in rural areas. This is expected since the target population of CCTs is typically the group of poor households with children and many programs targeted rural areas first. There are many studies analyzing the impact of CCTs on schooling. Fiszbein and Schady (2009, pp.129) review this literature and find that "virtually every [CCT] program that has had a credible evaluation has found a positive effect on school

\footnotetext{
${ }^{26}$ In the Online Appendix we provide the data as well as descriptive tables of these policies. See Appendix Table 4 and Appendix Table 5.
} 
enrollment". The impacts on enrollment reported in their study range from 0.5 to 12.8 percentage points. $^{27}$

Table 7: Change in Secondary School Graduation Rates (in \%) as Dependent Variable

\begin{tabular}{|c|c|c|c|c|c|c|c|c|}
\hline & \multicolumn{2}{|c|}{ Overall } & \multicolumn{2}{|c|}{ Income } & \multicolumn{2}{|c|}{ Geographic } & \multicolumn{2}{|c|}{ Gender } \\
\hline & & & Q1 & Q5 & Rural & Urban & Male & Female \\
\hline & [1] & [2] & [3] & [4] & [5] & [6] & [7] & [8] \\
\hline Public Education Expenditure/GDP (percent) & $\begin{array}{c}0.001 \\
{[0.778]}\end{array}$ & & & & & & & \\
\hline 1 (after introduction of CCT) & $\begin{array}{c}0.003 \\
{[0.523]}\end{array}$ & $\begin{array}{c}0.005 \\
{[0.204]}\end{array}$ & $\begin{array}{c}0.017^{*} \\
{[0.050]}\end{array}$ & $\begin{array}{c}0.000 \\
{[0.980]}\end{array}$ & $\begin{array}{c}0.009^{* *} \\
{[0.015]}\end{array}$ & $\begin{array}{c}0.002 \\
{[0.677]}\end{array}$ & $\begin{array}{c}0.006 \\
{[0.256]}\end{array}$ & $\begin{array}{c}0.005 \\
{[0.235]}\end{array}$ \\
\hline 1(after increase in years of compulsory duration) & $\begin{array}{c}0.002 \\
{[0.742]}\end{array}$ & $\begin{array}{c}0.007 \\
{[0.126]}\end{array}$ & $\begin{array}{c}0.004 \\
{[0.582]}\end{array}$ & $\begin{array}{c}0.002 \\
{[0.938]}\end{array}$ & $\begin{array}{c}0.015^{* * *} \\
{[0.000]}\end{array}$ & $\begin{array}{c}0.007 \\
{[0.282]}\end{array}$ & $\begin{array}{c}0.003 \\
{[0.440]}\end{array}$ & $\begin{array}{c}0.009^{*} \\
{[0.084]}\end{array}$ \\
\hline 1(after education decentralization) & $\begin{array}{c}0.016^{* * * *} \\
{[0.009]}\end{array}$ & $\begin{array}{c}0.015^{* * *} \\
{[0.003]}\end{array}$ & $\begin{array}{c}0.013^{* *} \\
{[0.048]}\end{array}$ & $\begin{array}{c}0.001 \\
{[0.872]}\end{array}$ & $\begin{array}{c}0.005 \\
{[0.384]}\end{array}$ & $\begin{array}{c}0.016^{* * *} \\
{[0.001]}\end{array}$ & $\begin{array}{c}0.012 \\
{[0.115]}\end{array}$ & $\begin{array}{c}0.019^{*} \\
{[0.052]}\end{array}$ \\
\hline 1(after introduction of 2 cycles in secondary school) & $\begin{array}{c}0.009^{*} \\
{[0.082]}\end{array}$ & $\begin{array}{c}0.009 * * \\
{[0.013]}\end{array}$ & $\begin{array}{c}0.014 * * * \\
{[0.006]}\end{array}$ & $\begin{array}{c}0.021 * * \\
{[0.025]}\end{array}$ & $\begin{array}{c}-0.001 \\
{[0.889]}\end{array}$ & $\begin{array}{c}0.013 * * \\
{[0.018]}\end{array}$ & $\begin{array}{c}0.008^{*} \\
{[0.088]}\end{array}$ & $\begin{array}{c}0.011^{*} \\
{[0.068]}\end{array}$ \\
\hline Constant & $\begin{array}{c}0.056^{* * * *} \\
{[0.002]}\end{array}$ & $\begin{array}{c}0.064 * * * \\
{[0.001]}\end{array}$ & $\begin{array}{c}0.027 \\
{[0.278]}\end{array}$ & $\begin{array}{c}0.046 \\
{[0.392]}\end{array}$ & $\begin{array}{c}0.056^{* * *} \\
{[0.000]}\end{array}$ & $\begin{array}{l}0.058 * * \\
{[0.028]}\end{array}$ & $\begin{array}{c}0.058^{* * * *} \\
{[0.004]}\end{array}$ & $\begin{array}{c}0.063 * * * \\
{[0.001]}\end{array}$ \\
\hline Observations & 278 & 360 & 360 & 360 & 260 & 320 & 360 & 360 \\
\hline R-squared & 0.084 & 0.096 & 0.063 & 0.115 & 0.319 & 0.102 & 0.063 & 0.086 \\
\hline Country Fixed Effects & $\mathrm{X}$ & $\mathrm{X}$ & $\mathrm{X}$ & $\mathrm{X}$ & $\mathrm{X}$ & $\mathrm{X}$ & $\mathrm{X}$ & $\mathrm{X}$ \\
\hline Control Variables & $\mathrm{X}$ & $\mathrm{X}$ & $\mathrm{X}$ & $\mathrm{X}$ & $\mathrm{X}$ & $\mathrm{X}$ & $\mathrm{X}$ & $\mathrm{X}$ \\
\hline
\end{tabular}

In Latin America education is predominantly provided via publicly administrated schools. About 75 percent of students in the region attend public schools that do not charge tuition for families and, depending on the country, are instead financed with tax revenue by the central, state or municipal government. ${ }^{28}$ Spending per student increased more than GDP per capita in most countries both in primary and secondary school. Argentina and Brazil are noticeable examples with 37 and 66 percent change in relative spending that basically took the level of spending in education over GDP to levels observed in countries with the highest performance in international student assessments. This increase in expenditure translated into an expansion of the number of public and private schools ${ }^{29,30}$ and in a decline of the student-teacher ratio of about 6 percent

\footnotetext{
${ }^{27}$ There is, however, large heterogeneity. Impacts are larger for populations with lower baseline enrollment and are larger for students transitioning from primary to secondary school (as opposed to students in primary or secondary school).

${ }^{28}$ The most notable exception to this financing scheme is Chile that has a voucher system which provides subsidies to families that can (at least potentially) choose among public or private schools.

${ }^{29}$ In many countries private schools are heavily subsidized either from the demand side (Chile) or from the supply side (Argentina). This system of subsidies helps explaining why an increase in public spending can lead to an increase in private school enrollment.
} 
over the last decade. ${ }^{31}$ It does not, however, appear to be correlated with graduation rates in the region. $^{32}$

Many Latin American countries implemented changes in their education systems. First, during the period 1990-2010 there have been changes in the mandatory years of education. Several countries changed the mandatory entry age to primary school or the mandatory finishing age of secondary school. Chile was the only country in Latin America to increase the number of mandatory years of education during the 1990s while Argentina, Brazil, and Uruguay did so during the 2000s. During the 2000s, Argentina, Nicaragua, and Uruguay increased the age at which mandatory education finishes, while the Dominican Republic and Paraguay decreased the entry age to primary education from 7 to 6 years old during the 1990s. These changed in the mandatory years of education seem to have had a small overall impact affecting only rural areas and female students.

Second, some countries decentralized the organization of their education systems. Argentina, Brazil and Chile have had a decentralized school organization since before 1990 with either states or municipalities being the main responsible for the organization of their schools. Other countries like Colombia, Mexico and Nicaragua implemented some decentralization reform during the period under analysis. We find that these reforms are associated to increases in graduation rates especially for students that live in poor and urban households.

Third, most countries in our samples switch in the late 1990s and early 2000s from a secondary school that lasted one cycle of five years to having two cycles (lower secondary and high school). These changes are also associated with higher graduation rates.

\footnotetext{
${ }^{30}$ Even though this holds for most countries, there are a few exceptions. Costa Rica and Bolivia, for instance, have experienced large expansions of their public schools system accompanied by contractions of the private provision of education while Chile and Uruguay have seen the opposite (the private sector expanding and the public sector declining).

${ }^{31}$ This decline is actually observed in most countries. In levels, though, the student-teacher ratio in the region doubles that of top countries and also shows great heterogeneity; ranging from 12 students per teacher in Argentina to 31 in Nicaragua.

${ }^{32}$ We only use this variable in column [2] because that data is available for a subset of the countries/years in the sample.
} 


\section{Challenges: Glass half empty}

A secondary school diploma is an essential requirement for entering today's highly competitive labor market. Even though the region experienced important improvements in educational outcomes during the last two decades fueled both by labor market incentives as well as by some policy changes, it still faces big challenges in order to catch up with developed economies. Graduation rates are still low when compared to more developed regions, there are large educational achievement gaps within countries, and Latin American students rank in the lowest percentiles of international tests such as PISA.

\subsection{Graduation rates are still low and heterogeneous}

Secondary school graduation rates in most developed countries are above 70 percent. Table 8 presents educational outcome statistics for the late 2000s. Latin America still shows a secondary school graduation rate that is low: only 45 percent of the secondary school age students actually graduate on time and among those that start secondary school only 60 percent finishes. Chile is probably the only country that is currently showing graduation rates that are similar to more developed economies. In most other countries graduation rates are much lower. In Costa Rica, Guatemala, Honduras, Nicaragua, and Uruguay less than 1 in 3 students graduate on time.

Problems start early-on during primary school and in the transition to lower secondary school. On average only 69 percent of those in secondary school age, and about 85 percent of those that actually finish primary school, are enrolled in secondary school. In other words, a first challenge

for Latin American countries is to improve educational outcomes in primary school, mainly by reducing overage, and to capture a larger proportion of students that do finish primary school but never make it to secondary. This is true for most countries but it is especially important for Guatemala, Nicaragua, and Honduras.

Second, dropout and overage rates among those that enroll in secondary school (i.e. conditional rates) are relatively high: 15 and 13 percent, respectively. About 1 in 3 of those students that start secondary school does not graduate on time. Thus, a second challenge for the region is to improve graduation and on-time grade promotion of those who do start secondary school. 
Needless to say, promotion and graduation require learning so it is important to identify interventions that help struggling students to keep up with their peers.

\begin{tabular}{|c|c|c|c|c|c|c|c|c|}
\hline & \multicolumn{2}{|c|}{ Enrollment } & \multicolumn{2}{|c|}{ Graduation } & \multicolumn{2}{|c|}{ Dropout } & \multicolumn{2}{|c|}{ Overage } \\
\hline & Unconditic & $\overline{\text { onditional }}$ & Unconditio & $\overline{\text { nditional }}$ & Unconditic & $\overline{\text { nditional }}$ & Unconditic & nditional \\
\hline & {$[1]$} & [2] & [3] & [4] & {$[5]$} & [6] & {$[7]$} & {$[8]$} \\
\hline Argentina & 0.77 & 0.88 & 0.56 & 0.67 & 0.22 & 0.12 & 0.11 & 0.12 \\
\hline Bolivia & 0.82 & 0.94 & 0.60 & 0.69 & 0.17 & 0.06 & 0.09 & 0.10 \\
\hline Brazil & 0.55 & 0.90 & 0.45 & 0.78 & 0.43 & 0.10 & 0.09 & 0.11 \\
\hline Chile & 0.87 & 0.94 & 0.74 & 0.80 & 0.13 & 0.06 & 0.08 & 0.08 \\
\hline Colombia & 0.73 & 0.90 & 0.47 & 0.59 & 0.25 & 0.10 & 0.17 & 0.20 \\
\hline Costa Rica & 0.66 & 0.85 & 0.30 & 0.44 & 0.34 & 0.15 & 0.22 & 0.27 \\
\hline Dominican Republic & 0.78 & 0.92 & 0.50 & 0.60 & 0.21 & 0.08 & 0.12 & 0.13 \\
\hline Ecuador & 0.83 & 0.90 & 0.61 & 0.67 & 0.17 & 0.10 & 0.05 & 0.05 \\
\hline Guatemala & 0.41 & 0.68 & 0.14 & 0.30 & 0.54 & 0.32 & 0.16 & 0.18 \\
\hline Honduras & 0.50 & 0.65 & 0.25 & 0.45 & 0.46 & 0.35 & 0.23 & 0.24 \\
\hline Mexico & 0.70 & 0.77 & 0.42 & 0.50 & 0.29 & 0.23 & 0.07 & 0.07 \\
\hline Nicaragua & 0.49 & 0.74 & 0.28 & 0.49 & 0.47 & 0.26 & 0.15 & 0.16 \\
\hline Panama & 0.73 & 0.85 & 0.49 & 0.61 & 0.26 & 0.15 & 0.12 & 0.12 \\
\hline Peru & 0.80 & 0.92 & 0.64 & 0.78 & 0.20 & 0.08 & 0.09 & 0.10 \\
\hline Paraguay & 0.62 & 0.79 & 0.48 & 0.68 & 0.37 & 0.21 & 0.06 & 0.06 \\
\hline El Salvador & 0.60 & 0.79 & 0.39 & 0.55 & 0.37 & 0.21 & 0.11 & 0.11 \\
\hline Uruguay & 0.72 & 0.82 & 0.28 & 0.35 & 0.28 & 0.18 & 0.16 & 0.18 \\
\hline Venezuela & 0.80 & 0.92 & 0.56 & 0.67 & 0.19 & 0.08 & 0.12 & 0.12 \\
\hline USA & 0.92 & 0.97 & 0.87 & 0.92 & 0.08 & 0.03 & 0.03 & 0.03 \\
\hline USA (latino pop.) & 0.91 & 0.97 & 0.83 & 0.88 & 0.09 & 0.03 & 0.04 & 0.04 \\
\hline LAC average & 0.69 & 0.85 & 0.45 & 0.60 & 0.30 & 0.15 & 0.12 & 0.13 \\
\hline LAC average (pop-weighted) & 0.66 & 0.86 & 0.47 & 0.65 & 0.33 & 0.14 & 0.10 & 0.11 \\
\hline
\end{tabular}

Table 9 shows gaps in graduation rates. Differences in graduation rates are typically larger by income than by location (urban-rural gap), and, in turn, the latter are larger than the gaps by gender. On average females have 8 percent higher graduation rates than males. This is a large gap taking into account that the average graduation rate is 45 percent. This gap is relatively homogeneous in the region with Argentina, Uruguay, Brazil, Dominican Republic, Venezuela and Panama showing larger gender gaps. The urban-rural graduation gap is much more important: individuals living in urban areas have 24 percent higher graduation rates than those living in rural areas. Regional gaps are larger in Colombia, Peru and Paraguay. Finally, persons 
living in households in the fifth income quintile have 35 percent higher graduation rates than those living in households in the first income quintile. ${ }^{33}$

Table 9: Graduation Gap

\begin{tabular}{|c|c|c|c|c|c|c|}
\hline & \multirow{2}{*}{\multicolumn{2}{|c|}{$\frac{\text { Female-Male }}{\text { Unconditional Conditional }}$}} & \multirow{2}{*}{\multicolumn{2}{|c|}{$\begin{array}{c}\text { Urban-Rural } \\
\text { Unconditional Conditional }\end{array}$}} & \multirow{2}{*}{\multicolumn{2}{|c|}{$\begin{array}{c}\text { Quntile 5- Quintile 1 } \\
\text { Unconditional Conditiona }\end{array}$}} \\
\hline & & & & & & \\
\hline & {$[1]$} & {$[2]$} & [3] & [4] & {$[5]$} & {$[6]$} \\
\hline \multicolumn{7}{|l|}{ Gap in late 2000 s } \\
\hline Argentina & 0.12 & 0.10 & - & - & 0.26 & 0.20 \\
\hline Bolivia & -0.02 & -0.02 & - & - & 0.31 & 0.32 \\
\hline Brazil & 0.13 & 0.06 & 0.27 & 0.19 & 0.54 & 0.34 \\
\hline Chile & 0.06 & 0.05 & 0.11 & 0.11 & 0.27 & 0.25 \\
\hline Colombia & 0.07 & 0.05 & 0.32 & 0.29 & 0.44 & 0.39 \\
\hline Costa Rica & 0.08 & 0.07 & 0.12 & 0.09 & 0.26 & 0.24 \\
\hline Dominican Republic & 0.18 & 0.15 & 0.18 & 0.15 & 0.35 & 0.30 \\
\hline Ecuador & 0.05 & 0.05 & - & & 0.35 & 0.32 \\
\hline Guatemala & 0.03 & 0.08 & 0.15 & 0.15 & 0.31 & 0.36 \\
\hline Honduras & 0.07 & 0.06 & 0.26 & 0.20 & 0.45 & 0.42 \\
\hline Mexico & 0.07 & 0.06 & 0.18 & 0.15 & 0.27 & 0.22 \\
\hline Nicaragua & 0.10 & 0.10 & 0.26 & 0.19 & 0.30 & 0.27 \\
\hline Panama & 0.13 & 0.13 & 0.28 & 0.20 & 0.43 & 0.34 \\
\hline Peru & 0.03 & 0.04 & 0.35 & 0.26 & 0.46 & 0.35 \\
\hline Paraguay & 0.08 & 0.06 & 0.32 & 0.29 & 0.36 & 0.25 \\
\hline El Salvador & 0.04 & 0.04 & 0.30 & 0.27 & 0.42 & 0.38 \\
\hline Uruguay & 0.13 & 0.13 & - & - & 0.38 & 0.35 \\
\hline Venezuela & 0.14 & 0.11 & - & - & 0.12 & 0.08 \\
\hline USA & 0.04 & 0.04 & 0.01 & 0.01 & 0.15 & 0.12 \\
\hline USA (latino pop.) & 0.05 & 0.04 & 0.01 & 0.00 & 0.18 & 0.15 \\
\hline LAC average & 0.08 & 0.07 & 0.24 & 0.19 & 0.35 & 0.30 \\
\hline LAC average (pop-weighted) & 0.10 & 0.06 & 0.25 & 0.19 & 0.40 & 0.30 \\
\hline
\end{tabular}

\subsection{Low quality of education}

As it has been largely documented, ${ }^{34}$ students in Latin America perform very poorly in international standardized tests. An example of this was the overall region's performance in the 2009 edition of PISA. Eight Latin American countries took the test. Table 10 shows results for 2000 and 2009 and presents gender, regional, and income gaps for 2009. Results correspond to the country's average score of math, reading, and science and values are standardized to have a

${ }^{33}$ Cruces, Domench and Gasparini (2012) found evidence too of big income gaps in years of education, school enrollment, wage skill differential, public social expenditure, school segregation, school achievement, and other topics.

${ }^{34}$ See, for example, Bassi et al. (2012) or Levy and Schady (2013). 
mean of 500 (which is the mean for the OECD countries) and a standard deviation of 100 . The last row shows the average of countries that performed the best. Chile and Uruguay had the highest scores in the region, while Panama and Peru the lowest. However, Latin American countries' scores were well below the OECD average and in the lower third of all the participating countries (Bassi et. al (2012)). Not even high income students' performance was close to the OECD standards. In addition to the overall bad results there are also big gaps within countries: males performed slightly worse than females, students in rural schools worse than those in urban schools, and poor students worse than relatively rich students.

Table 10: PISA results

\begin{tabular}{|c|c|c|c|c|c|c|c|c|}
\hline \multirow[t]{3}{*}{ Country } & \multicolumn{2}{|c|}{ Overall } & \multicolumn{2}{|c|}{ Gender (2009) } & \multicolumn{2}{|c|}{ Regional (2009) } & \multirow{2}{*}{\multicolumn{2}{|c|}{$\begin{array}{c}\text { Income (2009) } \\
\text { Quintile } 1 \text { Quintile } 5\end{array}$}} \\
\hline & 2000 & 2009 & Female & Male & Rural** $^{* *}$ & Urban & & \\
\hline & [1] & [2] & [3] & [4] & [5] & [6] & [7] & [8] \\
\hline Argentina & 400.7 & 395.7 & 400.9 & 389.7 & 376.9 & 421.4 & 350.0 & 442.8 \\
\hline Brazil & 401.7 & 401.0 & 402.5 & 399.3 & 390.0 & 413.5 & 371.3 & 435.7 \\
\hline Chile & 403.0 & 439.3 & 438.0 & 440.6 & 422.2 & 449.9 & 414.4 & 478.0 \\
\hline Colombia & $381.0 *$ & 398.6 & 391.6 & 406.3 & 381.8 & 417.2 & 362.4 & 441.2 \\
\hline Mexico & 410.3 & 419.9 & 420.7 & 419.1 & 397.9 & 446.5 & 391.2 & 455.9 \\
\hline Panama & - & 368.8 & 373.7 & 363.8 & 347.0 & 416.7 & 334.6 & 406.4 \\
\hline Peru & 317.3 & 368.1 & 368.1 & 368.0 & 336.3 & 420.2 & 310.3 & 429.5 \\
\hline Uruguay & $431.0 *$ & 426.6 & 431.4 & 421.2 & 412.0 & 445.5 & 392.6 & 461.7 \\
\hline USA & 498.7 & 496.4 & 494.8 & 497.9 & 500.4 & 490.1 & 461.8 & 525.2 \\
\hline LAC & 392.1 & 402.2 & 403.4 & 401.0 & 383.0 & 428.9 & 365.9 & 443.9 \\
\hline LAC (pop-weighted) & 392.7 & 404.4 & 404.9 & 403.8 & 387.6 & 425.0 & 371.4 & 443.1 \\
\hline
\end{tabular}

Note: Reported values equal the average of the math, science, and reading scores. Average score for the OECD in 2000 was 500 and in 2009 it was 498. Scores calculated using the final student weights of the PISA database. *Colombia 2006 and Uruguay 2003 values are used as 2000 values. Panama presented the first PISA test in 2009.** Rural variable does not exist in the PISA database, therefore we constructed it using the size of the village and the number of nearby schools.

Hanushek and Woessmann (2012) argue that the low quality of education in Latin America is a fundamental factor to explain why the region has underperformed in terms of growth relatively to countries that were similar or poorer in 1960: "In simplest terms, while Latin America has had reasonable school attainment, the skills of students remain comparatively very poor". The emphasis of the educational policy seems to have been put on increasing access to education rather than in increasing the quality of education. Moreover, Bassi et al. (2012) show that the secondary school education is not only of low quality but it also provides a set of skills that are not necessarily those demanded by the labor market. Indeed, increasing quality and pertinence of education can also be a way of increasing graduation rates by making school more attractive to students that will find it useful to enter the labor market or to continue studying. 


\section{Conclusion}

In this paper we document the main patterns in secondary school graduation and dropout in Latin America for 1990-2010. We find that enrollment and graduation rates increased during that period while dropout decreased. We provide several explanations for these patterns: countries have implemented policies to help students stay in school and returns to secondary education increased over the 1990s providing economic incentives to stay in school. Despite these positive changes, graduation rates are still low and there are important inequalities of opportunities observed in gender, income quintiles, and regional gaps within countries. Also, the region shows low quality of education. It is likely that that higher coverage and low quality are in fact related since the marginal student is likely more disadvantaged than students who already in school. This poses new challenges to secondary schools that have to increasingly work with students of more heterogeneous backgrounds and who also are more likely to drop out. These challenges should be addressed if we want to continue increasing graduation rates in the region. Identifying patterns, their explanations and where the main challenges are, constitutes a first step in that direction.

Providing policy advice on how to improve educational outcomes in the next decade is beyond the scope of this paper. Several recent meta-analyses discuss evidence-based education interventions of policies aimed at decreasing dropout and improving learning. Lately, several early identification and intervention systems for middle-grades schools to combat student disengagement which increase graduation rates have been identified for the US (Balfanz et al., 2007). There are also some experiences in developing nations that aim at getting children into school and keep them there (Petrosino et al., 2012). Finally, there have been an immense number of pilots and interventions to improve learning in developing countries. McEwan (2013) identifies 110 school-based treatments to affect language and mathematics test scores. He finds that nutritional treatments, treatments that provided information to parents or students, and treatments that improved school management and supervision had small effects. The largest effects included treatments with instructional materials, teacher training, instructional technology, smaller classes, smaller learning groups within classes, and student and teacher performance incentives. Finally, an important supply side constraint faced by the region seems to be the teachers. Levy and Schady (2013) argue that quality of teachers in the region is relatively 
low. Mizala and Nopo (2012) show that teachers earned lower wages compared to other professions within the same country and also have fewer human capital requirements.

\section{References}

Bassi, M., Busso, M., Urzúa, S., and Vargas, J. (2012). Disconnected. Skills, Education and Employment in Latin America. Washington, DC: IDB publications.

Balfanz, R., L. Herzog, and D. Mac Iver (2007). Preventing Student Disengagement and Keeping Students on the Graduation Path in Urban Middle-Grades Schools: Early Identification and Effective Interventions. Educational Psychologist, 42(4), 223-235

Barro, R. and J. Lee. (2013) A new data set of educational attainment in the world, 1950-2010, Journal of Development Economics, Volume 104, Pages 184-198,

Black, D., Mckinnish, T., and Sanders, S. (2005). Tight Labor Markets and the Demand for Education: Evidence from the Coal Boom and Bust. Industrial and Labor Relations Review, Vol 59 No.1 .

Cruces, G., García-Domench, C., and Gasparini, L. (2012). Inequality in Education: Evidence for Latin America. CEDLAS, working paper.

Dinkelman, T., and Martínez, C. (Forthcoming). Investing in Schooling in Chile: The Role of Information about Financial Aid for Higher Education. The Review of Economics and Statistics.

Eckstein, Z., and Wolpin, K. (1999). Why Youths Droup Out of High School: The Impact of Preferences, Opportunities, and Abilities. Econometrica, 1295-1339.

Edmonds, E., Pavcnick, N., and Topalova, P. (2010). Trade adjustments and Human Capital Investments: Evidence from Indian Tariff Reform. American Economic Journal: Applied Economics, 42-75.

Gasparini, L., Galiani, S., Cruces, G., and Acosta, P. (2011). Educational Upgrading and Returns to Skills in Latin America. The world bank policy research working paper 5921.

Fiszbein,A. and N. Schady (2009). Conditional Cash Transfers: Reducing Present and Future Poverty. World Bank Publications.

Foster, A., and Rosenzweig, M. (1996). Technical Change and Human-Capital Returns and Investments: Evidence from the Green Revolution. American Economic Review, 931-953. 
Foster, A., and Rosenzweig, M. (2004). Technological Change and the Distribution od Schooling: Evidence from Green-Revolution India. Journal of Development Economics, 87111.

Hanushek, E., and Woessmann, L. (2012). Schooling, educational achievement, and the Latin American growth puzzle. Journal of Development Economics, 497-512.

Heckman, J., and Lafontaine, P. (2010). The American High School Graduation Rate: Trends and Levels. The review of Economic and Statistics, $244-262$.

Jensen, R. (2010). The (perceived) Returns to Education and the Demand for Schooling. Quarterly Journal of Economics, 515-548.

Jensen, R. (2012). Do Labor Market Opportunities affect Young Women's Work and Family Decisions? Experimental Evidence from India. The Quarterly Journal of Economics, 1-40.

Levy, S., and Schady, N. (2013). Latin America's Social Policy Challenge: Education, Social Insurance, Redistribution. Journal of Economic Perspectives, 193-218.

Manacorda, M., Sánchez-Páramo, C., and Schady, N. (2010). Changes in Returns to Education in Latin America: The Role of Demand and Supply of Skills. Industrial and Labor Relations Review, 307-326.

McEwan, P. (2013). Improving Learning in Primary Schools of Developing Countries: A MetaAnalysis of Randomized Experiments, mimeo.

Mizala, A., and Ñopo, H. (2012). Salarios de los maestros en América Latina: ¿Cuánto (más o menos) ganan con respecto a sus pares? In M. Cabrol, and M. Székely, Educación para la transformación (pp. 167-204).

Murnane, R. J. (2013). "U.S. High School Graduation Rates: Patterns and Explanations." The Journal of Economic Literature 51(2): 370-422.

Navarro, J. C. (2007). Las reformas educativas como reformas del Estado: América Latina en las dos últimas décadas. In E. Lora, El estado de las reformas del Estado en América Latina (pp. 433-474). Washington DC: The Inter-American Development Bank.

Office of Evaluation and Oversight, OVE. (2013). Review of IDB Support to Secondary Education: Improving Access, Quality and Institutions, 1995-2012. Washington DC: InterAmerican Development Bank

Petrosino, A., C. Morgan, T. Fronius, E. Tanner-Smith, R. Boruch (2012). Interventions in developing nations for improving primary and secondary school enrolment of children: a systematic review. 3ie Working Paper.

Stampini, M., and Tornarolli, L. (2012). The growth of conditional cash transfers in Latin America and the Caribbean: Did they go too far? Washington DC: Inter-American Development Bank. Policy brief: IDB-PB-185. 


\section{Online Appendix I}

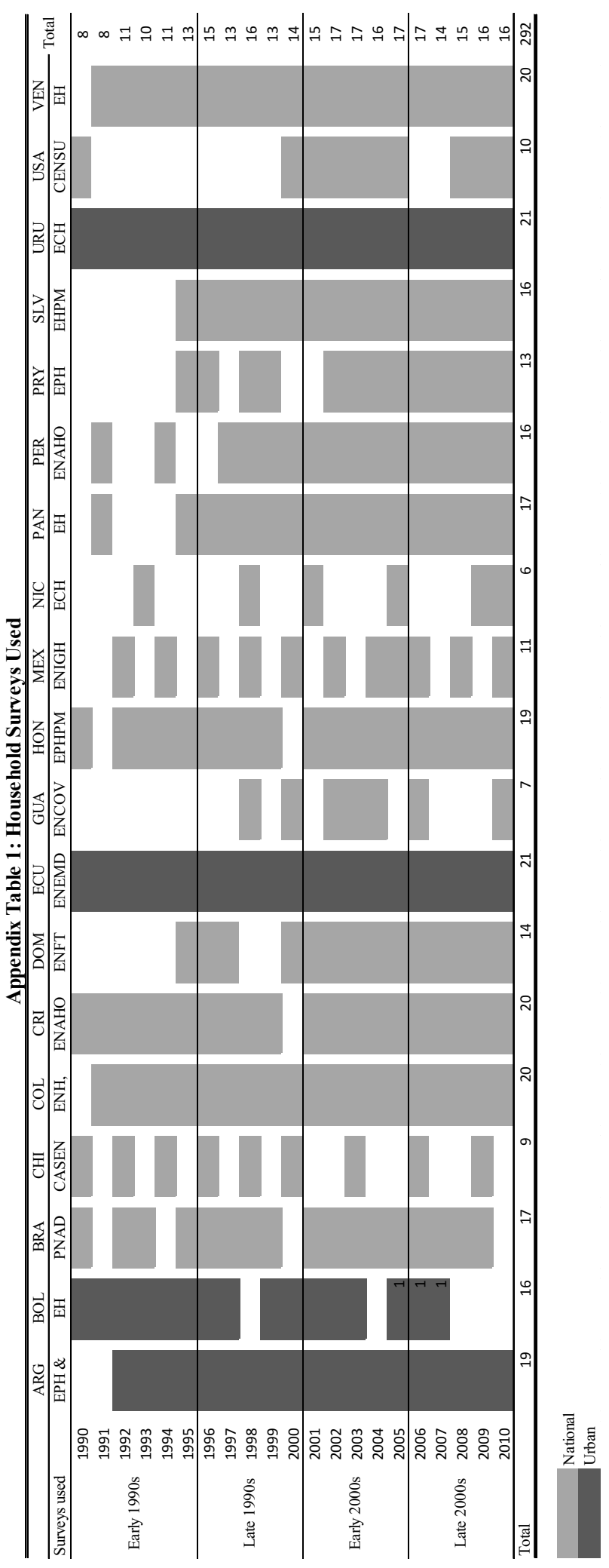



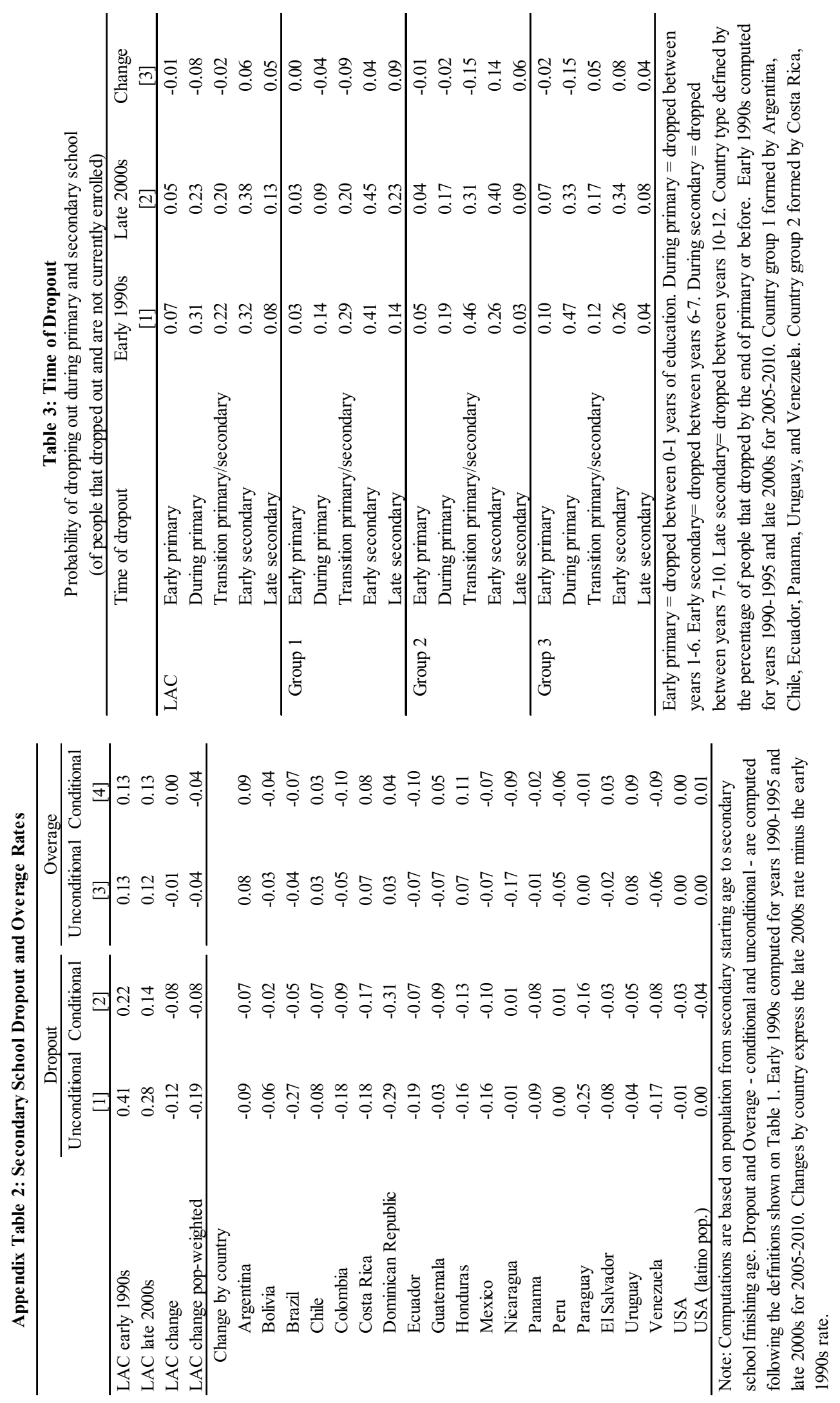
Online Table 4: Changes in Mandatory Years of Education

\begin{tabular}{|c|c|c|c|c|c|c|c|c|c|c|c|c|}
\hline \multirow[t]{2}{*}{ Country } & \multicolumn{2}{|c|}{$\begin{array}{c}\text { Primary School } \\
\text { Starting Age }\end{array}$} & \multicolumn{2}{|c|}{$\begin{array}{c}\text { Secondary } \\
\text { School Starting } \\
\text { Age }\end{array}$} & \multicolumn{2}{|c|}{$\begin{array}{c}\text { Duration of } \\
\text { Primary School }\end{array}$} & \multicolumn{2}{|c|}{$\begin{array}{l}\text { Duration of } \\
\text { Secondary } \\
\text { School }\end{array}$} & \multicolumn{2}{|c|}{$\begin{array}{c}\text { Ending Age of } \\
\text { Compulsory } \\
\text { Education }\end{array}$} & \multicolumn{2}{|c|}{$\begin{array}{l}\text { Duration of } \\
\text { Compulsory } \\
\text { education }\end{array}$} \\
\hline & $1990 \mathrm{~s}$ & $2000 \mathrm{~s}$ & $1990 \mathrm{~s}$ & $2000 \mathrm{~s}$ & $1990 \mathrm{~s}$ & $2000 \mathrm{~s}$ & $1990 \mathrm{~s}$ & $2000 \mathrm{~s}$ & $1990 \mathrm{~s}$ & $2000 \mathrm{~s}$ & $1990 \mathrm{~s}$ & $2000 \mathrm{~s}$ \\
\hline Argentina & & 6 & 13 & -12 & 7 & -6 & \multicolumn{2}{|c|}{$5-6$} & \multicolumn{2}{|c|}{$14-17$} & \multicolumn{2}{|c|}{$10-13$} \\
\hline Bolivia & & 6 & \multicolumn{2}{|r|}{12} & \multicolumn{2}{|r|}{6} & \multicolumn{2}{|r|}{6} & \multicolumn{2}{|r|}{13} & \multicolumn{2}{|r|}{8} \\
\hline Brazil & & 7 & \multicolumn{2}{|r|}{15} & \multicolumn{2}{|r|}{8} & & 3 & \multicolumn{2}{|r|}{14} & \multicolumn{2}{|c|}{$8-9$} \\
\hline Chile & & 6 & \multicolumn{2}{|r|}{12} & \multicolumn{2}{|r|}{6} & & 6 & \multicolumn{2}{|c|}{$13-17$} & \multicolumn{2}{|c|}{$8-12$} \\
\hline Colombia & & 6 & \multicolumn{2}{|r|}{11} & \multicolumn{2}{|r|}{5} & & 6 & \multicolumn{2}{|r|}{14} & \multicolumn{2}{|r|}{10} \\
\hline Costa Rica & & 6 & \multicolumn{2}{|r|}{12} & \multicolumn{2}{|r|}{6} & & 5 & \multicolumn{2}{|r|}{14} & \multicolumn{2}{|r|}{10} \\
\hline Dominican Republic & $7-$ & 6 & \multicolumn{2}{|c|}{$13-12$} & & 6 & & 6 & & 13 & & 9 \\
\hline Ecuador & & 6 & & 12 & & 6 & & 6 & & 14 & & 10 \\
\hline Guatemala & & 7 & & 13 & & 6 & & 6 & & 15 & & 10 \\
\hline Honduras & $7-$ & 6 & 13 & -12 & & 6 & & 5 & & 11 & & 6 \\
\hline Mexico & & 6 & & 12 & & 6 & & 6 & & 14 & & 11 \\
\hline Nicaragua & $7-$ & 6 & 13 & -12 & & 6 & & 5 & & 11 & & 6 \\
\hline Panama & & 6 & & 12 & & 6 & & 6 & & 14 & & 9 \\
\hline Peru & & 6 & & 12 & & 6 & & 5 & & 16 & & 12 \\
\hline Paraguay & $7-$ & 6 & & $3-12$ & & 6 & & 6 & & 14 & & 9 \\
\hline El Salvador & & 7 & & 13 & & 6 & & 6 & & 15 & & 9 \\
\hline Uruguay & & 6 & & 12 & & 6 & & 6 & & 17 & 10 & 14 \\
\hline Venezuela & & 6 & & 12 & & 6 & & 5 & & 16 & & 14 \\
\hline USA & & 6 & & 12 & & 6 & & 6 & & 17 & & 12 \\
\hline
\end{tabular}

Note: Data source is UNESCO stats.

Online Table 5: Supply

\begin{tabular}{|c|c|c|c|c|c|c|c|}
\hline & \multirow{2}{*}{$\begin{array}{c}\% \text { Public } \\
\text { Enrollment } \\
\text { Late } 2000 \mathrm{~s} \\
{[1]}\end{array}$} & \multicolumn{2}{|c|}{$\begin{array}{c}\text { Change in enrollment } \\
2000-2010\end{array}$} & \multicolumn{2}{|c|}{ Expenditure per student (\% GDP) } & \multicolumn{2}{|c|}{ Student-teacher ratio } \\
\hline & & $\begin{array}{c}\text { Public } \\
{[2]}\end{array}$ & $\begin{array}{c}\text { Private } \\
{[3]}\end{array}$ & $\begin{array}{c}\text { Late } 2000 \mathrm{~s} \\
{[4]}\end{array}$ & $\begin{array}{c}\text { Change 2000-2010 } \\
{[5]}\end{array}$ & $\begin{array}{c}\text { Late } 2000 \mathrm{~s} \\
{[6]}\end{array}$ & $\begin{array}{c}\text { Change 2000-2010 } \\
\text { [7] }\end{array}$ \\
\hline Argentina & 0.72 & 0.01 & 0.05 & 23.64 & 0.38 & 12.00 & -0.14 \\
\hline Bolivia & 0.87 & 0.32 & -0.49 & 15.55 & 0.37 & 18.00 & -0.24 \\
\hline Brazil & 0.87 & -0.08 & 0.01 & 19.33 & 0.67 & 17.50 & 0.04 \\
\hline Chile & 0.44 & -0.10 & 0.10 & 14.34 & 0.02 & 23.00 & -0.21 \\
\hline Colombia & 0.77 & 0.26 & 0.13 & 13.26 & -0.06 & 26.40 & 0.16 \\
\hline Costa Rica & 0.90 & 0.37 & 0.04 & 13.60 & -0.31 & 16.80 & -0.13 \\
\hline Dominican Republic & 0.78 & 0.20 & 0.13 & 6.07 & 0.46 & 27.00 & 0.02 \\
\hline Ecuador & 0.67 & 0.23 & 0.37 & 16.60 & 1.77 & 13.33 & -0.02 \\
\hline El Salvador & 0.82 & 0.21 & 0.00 & 8.93 & 0.02 & 26.25 & -0.11 \\
\hline Guatemala & 0.30 & 0.55 & 0.28 & 5.63 & 0.27 & 15.80 & 0.08 \\
\hline Honduras & 0.74 & 0.01 & & & & & \\
\hline Mexico & 0.85 & 0.16 & 0.06 & 14.32 & -0.11 & 18.00 & 0.04 \\
\hline Nicaragua & 0.76 & 0.28 & -0.05 & 5.60 & 0.87 & 31.00 & -0.06 \\
\hline Panama & 0.84 & 0.07 & 0.18 & 15.10 & -0.05 & 15.20 & -0.05 \\
\hline Paraguay & 0.79 & 0.10 & -0.02 & 16.70 & 0.09 & & \\
\hline Peru & 0.77 & -0.02 & 0.49 & 10.12 & 0.07 & 16.20 & -0.14 \\
\hline Uruguay & 0.85 & -0.13 & 0.17 & 10.60 & 0.22 & 13.00 & -0.12 \\
\hline Venezuela & 0.73 & 0.19 & 0.29 & & & & \\
\hline LAC & 0.75 & 0.15 & 0.10 & 13.09 & 0.29 & 19.30 & -0.06 \\
\hline LAC (pop-weighted) & 0.80 & 0.07 & 0.09 & 15.90 & 0.32 & 18.57 & 0.01 \\
\hline United States & 0.91 & 0.05 & -0.01 & 23.85 & 0.04 & 14.26 & -0.04 \\
\hline
\end{tabular}


Appendix Figure 1: Primary School Graduation Rate Trends

A) Sub-region

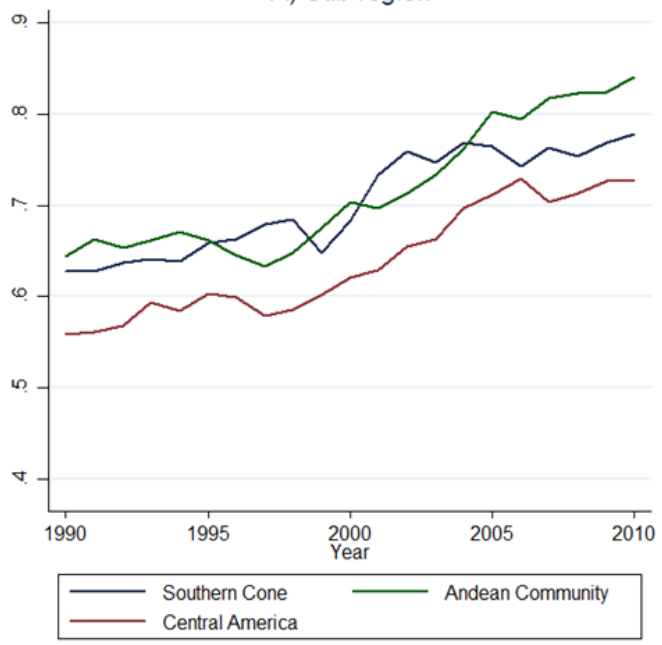

B) Starting Graduation Rate

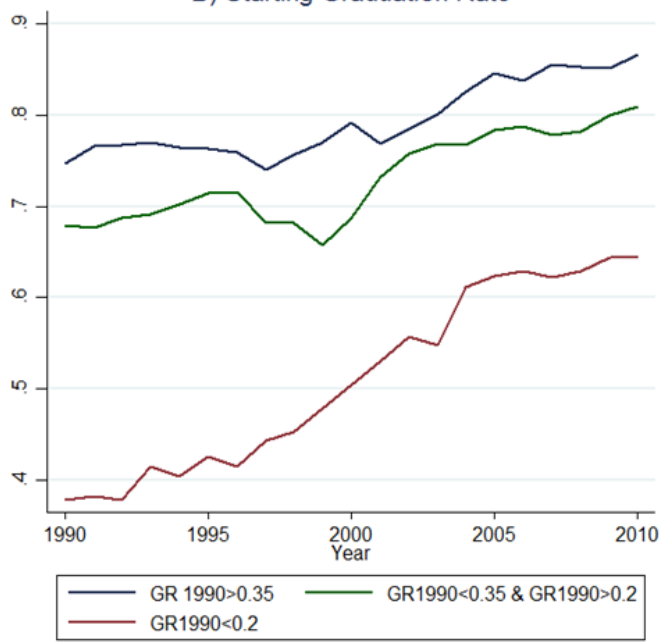

Note: Graduation rate computed on the population with (secondary school starting age +1 ) years old. For the years in which no data was available we computed the mean between the latest and the next available values. If the missing value was not in between two avalable years then we replaced it by the nearest year. The values reported are the simple average between LAC countries. Southern cone includes Argentina, Chile, Uruguay, Paraguay, and Brazil. Andean Community include Colombia, Ecuador, Bolivia, Peru, and Venezuela. Central America is composed by Panama, Costa Rica, Dominic an Republic, Guatemala, Honduras, Nicaragua, El Salvador, and Mexico. In the panel B of the graph the group $>0.35$ includes: Argentina, Bolivia, Chile, Ecuador, Panama, and Peru. The group with GR $<0.35$ and $>0.2$ includes: Costa Rica, Dominican Republic, Mexico, El Salvador, Uruguay, Venezuela. Finally, the group with GR $<0.2$ includes: Brasil, Colombia, Guatemala, Honduras, Nicaragua, and Paraguay.

\section{Appendix Figure 2: Gender Gaps in Graduation rates (LAC Average)}
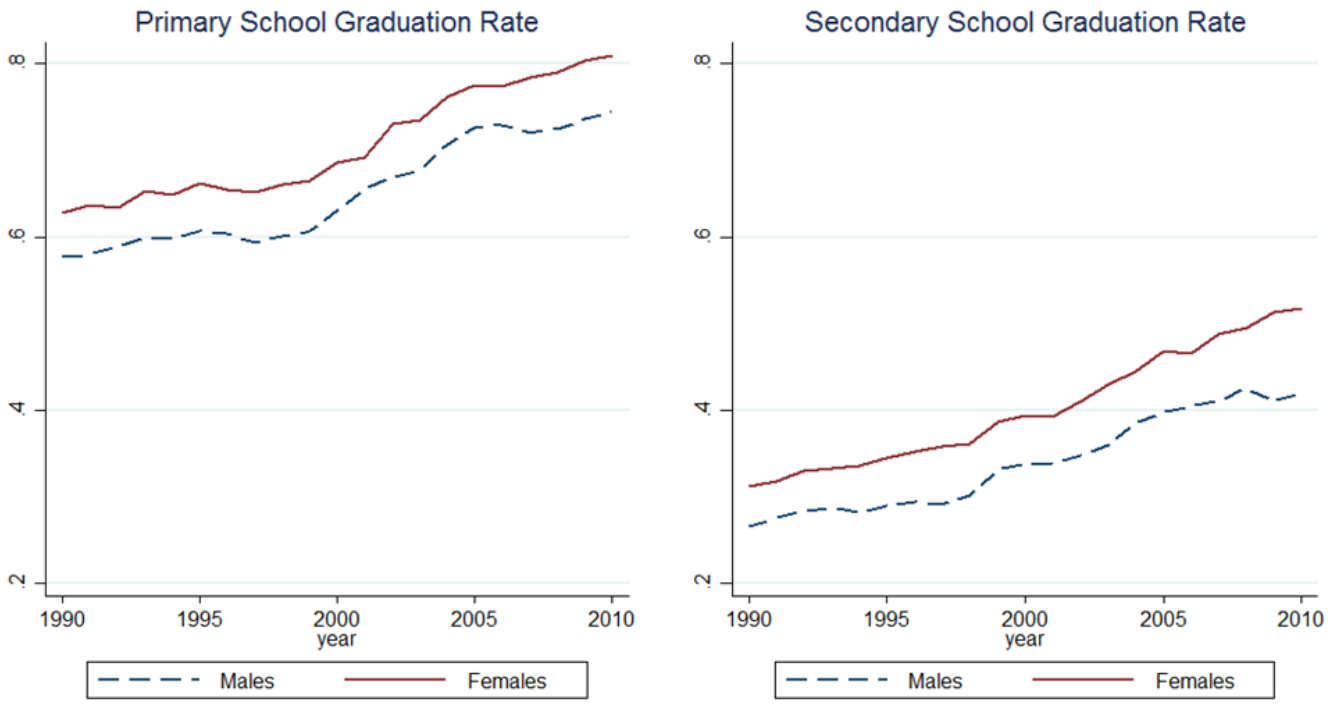

Note: Primary school graduation rate computed on the population with (secondary school starting age +1 ) years old. Secondary school graduation rate computed on the population with (secondary ending age +1 ) years old. For the years in which no data was available we computed the mean between the latest and the next available values. If the missing value was not in between two available years then we replaced it by the nearest year. The values reported are the simple average between LAC countries. Values reported correspond the gender graduation rates. 
Appendix Figure 3: Geographic Gaps in Graduation rates (LAC Average)
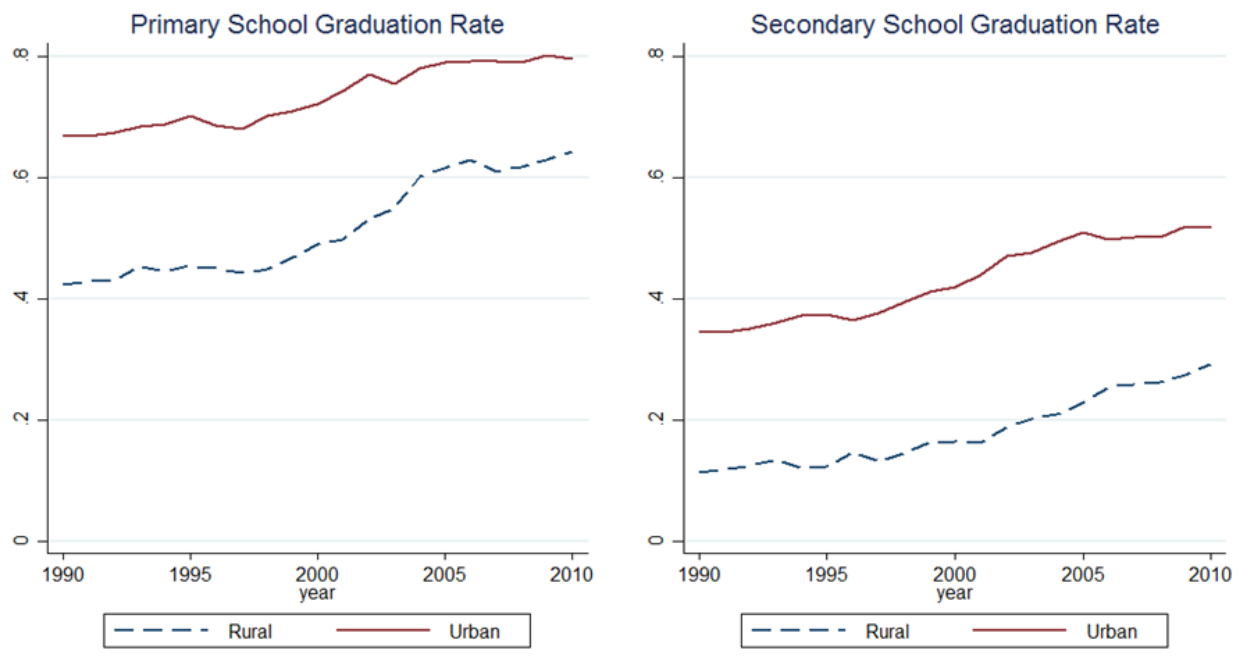

Note: Primary school graduation rate computed on the population with (secondary school starting age +1 ) years old. Secondary school graduation rate computed on the population with (secondary ending age +1 ) years old. For the years in which no data was available we computed the mean between the latest and the next available values. If the missing value was not in between two available years then we replaced it by the nearest year. The values reported are the simple average between LAC countries. Vahues reported correspond the urban and rural graduation rates.

Appendix Figure 4: Income Gaps in Graduation rates (LAC Average)
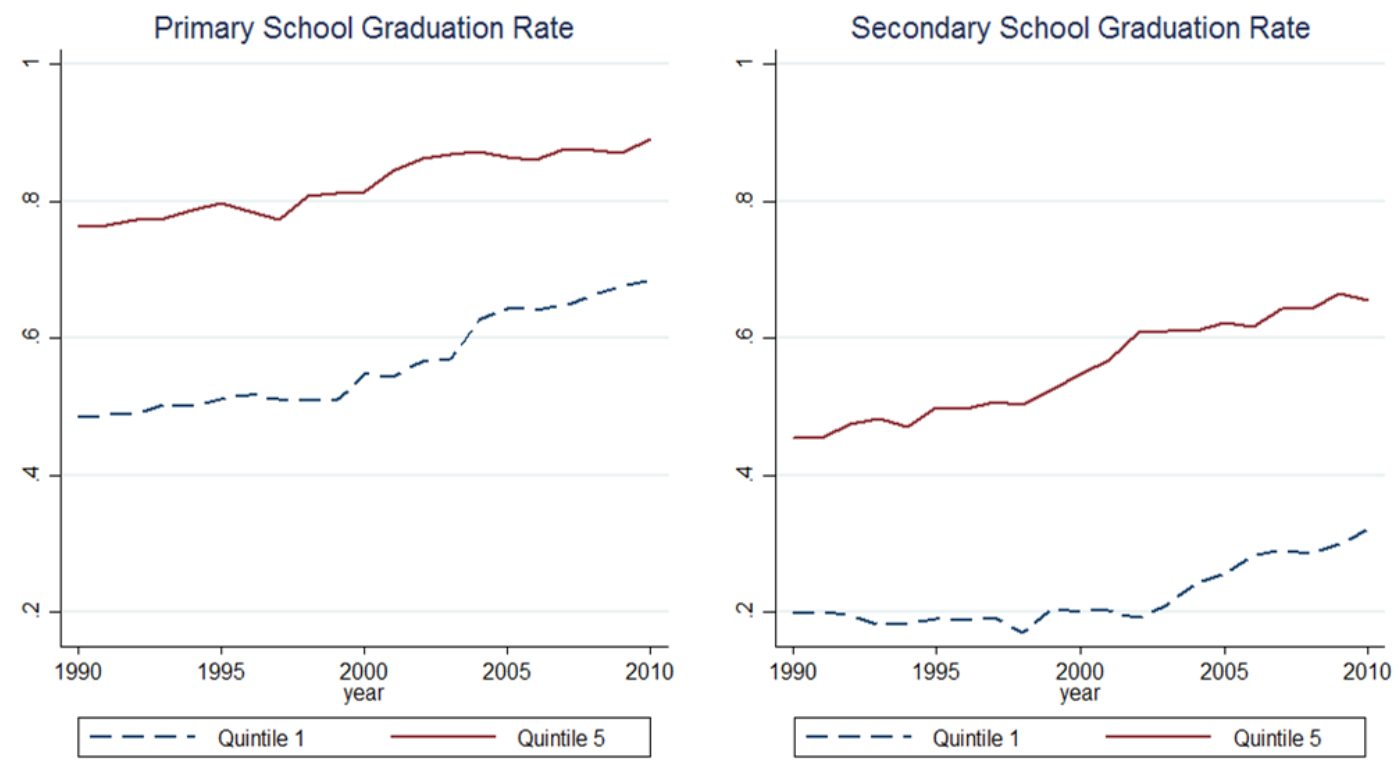

Note: Primary school graduation rate computed on the population with (secondary school starting age +1 ) years old. Secondary school graduation rate computed on the population with (secondary ending age +1 ) years old. For the years in which no data was available we computed the mean between the latest and the next available values. If the missing value was not in between two available years then we replaced it by the nearest year. The vahues reported are the simple average between LAC countries. Vahes reported correspond the first and last income quintiles graduation rates. 